\title{
A Stage-Oriented Model (SOM) for E-Commerce Adoption: a study of Saudi Arabian Organisations
}

\section{Purpose}

The purpose of this work was to construct a new E-commerce innovation and adoption model that takes into account various stages of e-commerce adoption (interactive, non-interactive and stabilised) and covers technological, organisational and environmental factors. This was tested using data collected from manufacturing and service companies in Saudi Arabia to reveal inhibitors and catalysts for E-commerce adoption.

\section{Design/methodology/approach}

This study uses new data from surveys from 202 companies and then uses exploratory factor analysis and structural equation modelling for analyses.

\section{Findings}

This study shows that the new Stage Oriented Model (SOM) is valid and can reveal specific detailed nuances of E-commerce adoption within a particular setting. Surprising results show that Saudi Arabia is not so very different to developed Western countries in respect to E-commerce adoption. However there are some important differences which are discussed in detail.

\section{Research limitations/implications}

A new stage oriented model (SOM) for e-commerce adoption is provided which may be used by other IS adoption researchers.

\section{Practical implications}

Managers responsible for the adoption of E-commerce in SA, the Middle East and beyond can learn from these findings to speed up adoption rates and make E-commerce more effective.

\section{Social implications}

This work may help spread E-commerce use throughout Saudi Arabia, the Middle East and to other developing nations.

\section{Originality/value}

The results add to the extremely limited number of empirical studies that has been conducted to investigate E-commerce adoption in the context of Arabic countries.

Keywords: E-commerce, Saudi Arabia, Innovation Diffusion, Technology Adoption, IS strategy 


\section{Introduction}

B2B electronic commerce (hereafter 'E-commerce') has enabled many organisations to share information, cooperate with business partners and collaborate across geographical boundaries. Indeed, Electronic commerce offers unique opportunities to both developing and developed countries. In the short term, the gains are likely to be concentrated in developed countries but, in the long term, developing countries have more to benefit (Terzi, 2011). In fact, E-commerce and its adoption has gained much interest from practitioners, scholars and policy makers alike over recent decades resulting in various models to help explain the facilitators and inhibitors of Ecommerce adoption in organisations (Dilworth and Kochhar 2007, Molla and Licker 2005a, 2005b, Zhu et al. 2003). E-commerce adoption in developing countries is more complex due to challenges such as insufficient regulatory environments and inadequate infrastructure; and so there is a particular need to study less developed countries. The aim of this study is to provide a validated model of e-commerce adoption for Saudi Arabia and develop a clear understanding about the different factors that support and or impede the adoption process.

Saudi Arabia is one of the twenty largest economies in the world, a G20 member and is a rapidly developing economy, it has a population of over 27 million (2010) growing at a rate of $3.76 \%$ per annum (World Economic Forum 2012). Saudi Arabia has a diverse immigrant population and a highly homogenised indigenous culture. Therefore Saudi Arabia is an interesting and important country to study indicative of many in the Arab world and Middle East. Studies such as this are rare, as data are usually difficult to collect and interpret in developing Arab countries.

This paper is organized as follows. Firstly a review of the e-commerce adoption in developing countries is presented, followed by an analysis of the context in Saudi Arabia. Next the paper outlines the theoretical background of innovation adoption models and the research method, followed by a discussion of the new Stage-Orientated Model (SOM). Findings from testing the model are then presented. Wider research implications conclude the paper.

\section{E-commerce Factors in Developing Arab Countries}

It has been shown that there are significant differences between how e-business matures successfully in developed countries (such as the US, Canada, and Western Europe) and less developed countries (Hawk 2004). Thus, theories and management practices originating from developed countries in the West need to be re-examined in the context of developing countries to 
better fit the cultural context of the recipient nation (Hofstede 1980). In fact, studies conducted in Western countries tend to embody the values, attitudes, and beliefs of the West, which are different from those of non-Western cultures (Marasini et al. 2008, Hafeez et al. 2006). Moreover, issues which might seem trivial for developed countries may play an important role for E-commerce adoption in developing countries. For instance, in most developing countries, Ecommerce adoption has been constrained by an insufficient regulatory environment and an inadequate or inaccessible information and communication technology (ICT) infrastructure.

Many researchers note that in developing countries there is a lack of awareness and understanding about the advantages and risks of E-commerce among business organisations and their employees, leading to a negative cognitive assessment of E-commerce (Kshetri 2007, Molla, A. and Licker 2005a, 2005b). Also, organisations in developing countries fail to make use of E-commerce because of top managements' unwillingness to adopt E-commerce, lack of proficiency in English and lack of computer literacy among employees (Gibbs et al., 2003, Kshetri 2007). In general, the perception of the managers in respect to E-commerce adoption in developing countries is likely to be sceptical.

Saudi Arabia is the largest oil-exporting country in the world and its oil revenue has given the country financial capital to invest in new industrial plants and ICT infrastructure. The economic problems which Saudi Arabia experienced in the mid 80's, due to the unfavourable oil prices encouraged its government to move beyond an economy being purely dependent on oil exports to become a more diverse, robust and competitive economy, which in turn helped its ICT sector to grow. Hence ICT data on Arab and Middle Eastern nations as shown in Table 1 shows that Saudi Arabia tops the PC ownership rankings in the region (69.8\%). This was due in part to initiatives such as the Home Computer Project launched in 2004 which helped to increase reach of the E-Government systems to households. However, on the downside the government still needs to encourage its population to go online more, as Table 1 also demonstrates that the percentage of Internet users (41\%), secure Internet servers per million of the population (22), telephone lines per 100 of the population (16.64) and price per basket spent per month (\$123 USD) is relatively low when compared to other countries in the region. 
Table 1: Background ICT Data for Developing Arab Countries in the Middle East

\begin{tabular}{|c|c|c|c|c|c|c|c|c|c|}
\hline Country & Region & Income category & $\begin{array}{c}\text { Population } \\
(\text { millions) } \\
(2010)^{a}\end{array}$ & $\begin{array}{c}\text { Internet } \\
\text { users (per } \\
100 \text { people) } \\
{(2010)^{a}}^{a}\end{array}$ & $\begin{array}{l}\text { Secure Internet } \\
\text { servers }{ }^{1} \text { per } \\
\text { million } \\
\text { population } \\
(2011)^{\mathrm{a}}\end{array}$ & $\begin{array}{c}\text { Personal } \\
\text { computers } \\
(\text { PC) per 100 } \\
\text { population } \\
(\mathbf{2 0 0 8})^{b}\end{array}$ & $\begin{array}{l}\text { Telephone } \\
\text { lines per } \\
100 \text { people } \\
(2008)^{\mathrm{c}}\end{array}$ & $\begin{array}{c}\text { Internet } \\
\text { hosts }(2010)^{c}\end{array}$ & $\begin{array}{c}\text { Price basket for } \\
\text { Internet - } \\
\text { US\$/month } \\
(2009)^{\mathrm{a}}\end{array}$ \\
\hline Algeria & $\begin{array}{l}\text { Middle East and } \\
\text { North Africa }\end{array}$ & $\begin{array}{l}\text { Upper-middle- } \\
\text { income }\end{array}$ & $35,468,000$ & $12.5 \%$ & 1 & 1.07 & 9.64 & 561 & 117.22 \\
\hline Bahrain & Arabian Gulf & High-income & $1,262,000$ & $55.0 \%$ & 118 & 74.6 & 28.42 & 46,035 & 112.09 \\
\hline Egypt & $\begin{array}{l}\text { Middle East and } \\
\text { North Africa }\end{array}$ & $\begin{array}{l}\text { Lower-middle- } \\
\text { income }\end{array}$ & $81,121,000$ & $26.7 \%$ & 3 & 3.92 & 14.64 & 200,336 & 155.61 \\
\hline Iraq & $\begin{array}{l}\text { Middle East and } \\
\text { North Africa }\end{array}$ & $\begin{array}{l}\text { Lower-middle- } \\
\text { income }\end{array}$ & $32,031,000$ & $2.5 \%$ & $\mathrm{n} / \mathrm{a}$ & 1 & 3.52 & 23 & $\mathrm{n} / \mathrm{a}$ \\
\hline Jordan & $\begin{array}{l}\text { Middle East and } \\
\text { North Africa }\end{array}$ & $\begin{array}{l}\text { Lower-middle- } \\
\text { income }\end{array}$ & $6,047,000$ & $38.9 \%$ & 25 & 7.48 & 8.79 & 49,083 & 127.82 \\
\hline Kuwait & Arabian Gulf & High-income & $2,736,000$ & $38.3 \%$ & 180 & 22.22 & 19.83 & 2,730 & 124.99 \\
\hline Lebanon & $\begin{array}{l}\text { Middle East and } \\
\text { North Africa }\end{array}$ & $\begin{array}{l}\text { Upper-middle- } \\
\text { income }\end{array}$ & $4,227,000$ & $31.0 \%$ & 41 & 10.18 & 17.88 & 64,525 & 103.41 \\
\hline Libya & $\begin{array}{l}\text { Middle East and } \\
\text { North Africa }\end{array}$ & $\begin{array}{l}\text { Upper-middle- } \\
\text { income }\end{array}$ & $6,355,000$ & $14.0 \%$ & 1 & 2.19 & 16.41 & 17,787 & 121.90 \\
\hline Mauritania & Sub-Saharan Africa & Low-income & $3,460,000$ & $3.0 \%$ & 2 & 4.54 & 2.37 & 28 & 125.04 \\
\hline Morocco & $\begin{array}{l}\text { Middle East and } \\
\text { North Africa }\end{array}$ & $\begin{array}{l}\text { Lower-middle- } \\
\text { income }\end{array}$ & $31,951,000$ & $49.0 \%$ & 4 & 5.70 & 9.46 & 15 & 110.39 \\
\hline Oman & Arabian Gulf & High-income & $2,783,000$ & $62.0 \%$ & 53 & 16.88 & 9.84 & 13,488 & 127.40 \\
\hline Qatar & Arabian Gulf & High-income & $1,759,000$ & $81.6 \%$ & 126 & 15.69 & 20.56 & 887 & 139.25 \\
\hline Saudi Arabia & Arabian Gulf & High-income & $27,448,000$ & $41.0 \%$ & 22 & 69.8 & 16.64 & 147,202 & 122.90 \\
\hline Syria & $\begin{array}{l}\text { Middle East and } \\
\text { North Africa }\end{array}$ & $\begin{array}{l}\text { Lower-middle- } \\
\text { income }\end{array}$ & $20,447,000$ & $20.7 \%$ & $\mathrm{n} / \mathrm{a}$ & 8.78 & 17.12 & 420 & 136.19 \\
\hline Tunisia & $\begin{array}{l}\text { Middle East and } \\
\text { North Africa }\end{array}$ & $\begin{array}{l}\text { Lower-middle- } \\
\text { income }\end{array}$ & $10,549,000$ & $36.6 \%$ & 19 & 9.66 & 12 & 575 & 117.43 \\
\hline $\begin{array}{l}\text { United Arab } \\
\text { Emirates }\end{array}$ & Arabian Gulf & High-income & $7,512,000$ & $78.0 \%$ & 180 & 33.08 & 33.63 & 371,969 & $\mathrm{n} / \mathrm{a}$ \\
\hline Yemen & $\begin{array}{l}\text { Middle East and } \\
\text { North Africa }\end{array}$ & $\begin{array}{l}\text { Lower-middle- } \\
\text { income }\end{array}$ & $24,053,000$ & $12.3 \%$ & $\mathrm{n} / \mathrm{a}$ & 2.77 & 4.87 & 33,279 & 147.53 \\
\hline
\end{tabular}

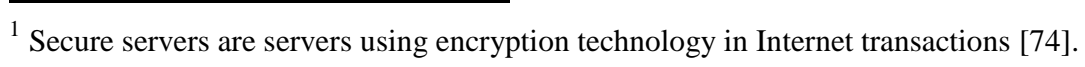


Further research conducted by King Abdul Aziz City of Science and Technology (KACST) ${ }^{2}$ found that $67 \%$ of Saudi Arabian companies do not yet have Internet access and out of those companies with access $57 \%$ do not use the Internet at all, and only $10 \%$ have an Internet presence (KACST Business Sector Survey 2006). Therefore there is much that can be done in Saudi Arabia to encourage the update of E-commerce. Constructs that were found to be most relevant to this subject are shown in Table 2.

\footnotetext{
${ }^{2}$ KACST is a government institution that formulates the rules that govern the use of the Internet in Saudi Arabia and also governs the Saudi domain. KACST is also responsible for filtering international Internet traffic to the Kingdom.
} 
Table 2. Description of the Research Model Constructs

\begin{tabular}{|c|c|c|}
\hline Construct & Definition & References \\
\hline \multicolumn{3}{|l|}{ Technology } \\
\hline Relative Advantage & $\begin{array}{l}\text { The advancement of existing conditions derived from the innovation, such as economic benefits, cost reductions, improved } \\
\text { image, progress, convenience and satisfaction. }\end{array}$ & $\begin{array}{l}\text { Wu et al. (2003), Zhu \& } \\
\text { Kraemer (2005), } \\
\text { Zhu et al. (2003) }\end{array}$ \\
\hline Compatibility & $\begin{array}{l}\text { The degree to which an innovation is perceived as being consistent with the existing values, needs and previous experiences } \\
\text { of potential users or adopters. }\end{array}$ & Rogers (1995) \\
\hline Cost & $\begin{array}{l}\text { The costs of implementing necessary technologies for on-line transactions, including initial development investments and } \\
\text { recurring operating expenses (i.e. adoption direct and indirect cost). }\end{array}$ & Zhu et al. (2006) \\
\hline Security concern & The extent to which the e-commerce technology is believed insecure for exchanging data and conducting online transactions & Zhu et al. (2006) \\
\hline Language Barrier & The extent to which e-commerce technology is believed to be free of language barriers. & $\begin{array}{l}\text { Field interviews along with: } \\
\text { Alam (2009) } \\
\text { Salman (2004) }\end{array}$ \\
\hline \multicolumn{3}{|l|}{ Organisational } \\
\hline IT readiness & $\begin{array}{l}\text { Organisational IT readiness referred to the technology infrastructure and employees' IT knowledge. Technology } \\
\text { infrastructure refers to hardware, operating systems and software resources that enable Internet-related businesses (e.g. } \\
\text { Intranet and extranet), while employees' IT knowledge refer to IT professionals possessing the knowledge and skills to use } \\
\text { and implement Internet-related applications effectively. IT knowledge includes employees' knowledge of programming, } \\
\text { website design, systems analysis and design, internet security knowledge and competencies in emerging technologies. }\end{array}$ & $\begin{array}{l}\text { Doolin et al. (2003) } \\
\text { Molla, A. and Licker (2005a, } \\
\text { 2005b) } \\
\text { Zhu et al. (2003) }\end{array}$ \\
\hline $\begin{array}{l}\text { Management team } \\
\text { support }\end{array}$ & The extent to which executive management explicitly encourage the use of new innovation and technology. & $\begin{array}{l}\text { Soliman \& Janz (2004) } \\
\text { Wu et al. (2003) }\end{array}$ \\
\hline Learning orientation & $\begin{array}{l}\text { The extent to which an organisation creates, acquires, shares, and transfers knowledge and modifies its behaviour to reflect } \\
\text { new knowledge and insights. }\end{array}$ & Wu et al. (2003) \\
\hline $\begin{array}{l}\text { Receptivity toward } \\
\text { change }\end{array}$ & $\begin{array}{l}\text { Organisational members' proclivity, willingness, and inclination to engage in innovative behaviour and adopt ideas that } \\
\text { departs from the usual or old way of approaching business. }\end{array}$ & $\begin{array}{l}\text { Francalanci \& Morabito } \\
\text { (2008) } \\
\text { Molla, A. and Licker } \\
(2005 \mathrm{a}, 2005 \mathrm{~b})\end{array}$ \\
\hline Strategic orientation & $\begin{array}{l}\text { The philosophy of firms and how they interact with external environments to conduct business. This includes (1) firm's } \\
\text { understanding of its target buyers or consumers (2) the ability and the will of the firm to identify, analyse, and respond to } \\
\text { competitors' actions, and ( } 3 \text { ) the long-range strategy of an organisation to acquire new technology that affects the } \\
\text { development of new ideas, new processes and new products or service. }\end{array}$ & $\begin{array}{l}\text { Kohli \& Jaworski (1990) } \\
\text { Salavou et al. (2004), Wu et } \\
\text { al. } 2003\end{array}$ \\
\hline Formalisation level & The presence of written rules, procedures, and documents. & \multirow{2}{*}{$\begin{array}{l}\text { Damanpour (1991), } \\
\text { Hair et al. (1995) }\end{array}$} \\
\hline $\begin{array}{l}\text { Decentralization } \\
\text { level }\end{array}$ & The degree to which decision making is pushed down to lower-level managers and employees & \\
\hline
\end{tabular}


Table 2 (Cont.)

\begin{tabular}{|c|c|c|}
\hline Construct & Definition & References \\
\hline \multicolumn{3}{|l|}{ Environmental } \\
\hline $\begin{array}{l}\text { Market Force } \\
\text { influence }\end{array}$ & The assessment of an organisation's business partners, customers and suppliers ability to conduct electronic business. & $\begin{array}{l}\text { Lin \& Lin (2008) } \\
\text { Soliman \& janz (2004) } \\
\text { Wu et al. (2003) } \\
\text { Matopoulos } \text { et al. } \\
\text { (2009) }\end{array}$ \\
\hline $\begin{array}{l}\text { Economic downturn } \\
\text { influence }\end{array}$ & $\begin{array}{l}\text { The extent to which the recent global economic downturn added additional downward pressure on e-commerce investment } \\
\text { among businesses. Financial constraints are particularly significant in the adoption and diffusion process of an innovation. }\end{array}$ & $\begin{array}{l}\text { Field interviews along } \\
\text { with: } \\
\text { MacGregor, \& Vrazalic } \\
\text { (2006a, 2006b) }\end{array}$ \\
\hline Competitive pressure & The level of e-commerce capability in the firm's industry and of its competitors. & $\begin{array}{l}\text { Iacovou et al. }(1995) \\
\text { Lin \& Lin }(2008) \mathrm{Wu} \\
\text { et al }(2003)\end{array}$ \\
\hline $\begin{array}{l}\text { Regulatory \& Legal } \\
\text { environment }\end{array}$ & $\begin{array}{l}\text { Organisations' assessment of the preparation of the nation state and its various institutions to promote, support, facilitate and } \\
\text { regulate e-commerce and its various requirements. }\end{array}$ & $\begin{array}{l}\text { Field interviews along } \\
\text { with: } \\
\text { Ramsey \& McCole } \\
(2005)\end{array}$ \\
\hline National e-readiness & $\begin{array}{l}\text { Availability of good and sufficient national infrastructure (high bandwidth, affordable prices, transportation infrastructure, } \\
\text { banking infrastructure and skilled workforce). }\end{array}$ & $\begin{array}{l}\text { Molla \& Licker } \\
\text { (2005a, 2005b) } \\
\text { Soliman \& Janz (2004) }\end{array}$ \\
\hline $\begin{array}{l}\text { Technology } \\
\text { consultants' } \\
\text { participation }\end{array}$ & $\begin{array}{l}\text { Support and advice from technology consultants and IT vendors in order to adopt the technology. Consultancy service can } \\
\text { involve performing information requirements analysis of business needs, recommending suitable computer hardware and } \\
\text { software, and managing implementation of the information systems }\end{array}$ & $\begin{array}{l}\text { Thong et al. (1994, } \\
\text { 1996) }\end{array}$ \\
\hline \multicolumn{3}{|c|}{ E-commerce Adoption - self assessment } \\
\hline $\begin{array}{l}\text { Non-interactive } \\
\text { Adoption }\end{array}$ & Indicates whether or not an organisation has attained e-mail access or a static web presence & \multirow{3}{*}{$\begin{array}{l}\text { Molla \& Licker } \\
(2005 a, 2005 b)\end{array}$} \\
\hline Interactive Adoption & $\begin{array}{l}\text { A business is considered to have adopted interactive e-commerce if it has established an interactive web presence by } \\
\text { establishing two-way communication on the Internet involving online orders, feedback, and other forms of interactions such } \\
\text { as accepting queries from users. }\end{array}$ & \\
\hline $\begin{array}{l}\text { Stabilisation of e- } \\
\text { commerce. }\end{array}$ & $\begin{array}{l}\text { Indicates whether or not an organisation has attained an interactive, or transactive or integrated e-commerce in which most } \\
\text { of the business transactions are conducted electronically (i.e. inventory update, electronic paperwork and receipts). }\end{array}$ & \\
\hline
\end{tabular}




\section{Conceptual Modelling for E-commerce Adoption}

Innovation is a fundamental concept of economic growth and is often an enabler for achieving sustainable competitiveness for organisations. Innovation adoption and diffusion has been studied since the early 1940s and researchers have identified factors that affect organisational innovation adoption in order to enhance its usage. Several theoretical models and frameworks have their roots in information systems, psychology and sociology (Venkatesh et al. 2003).

This study used the Technology-Organization-Environment (TOE) framework ${ }^{3}$ to identify determinants of E-commerce adoption as developed by Tornatzky and Fleischer (1990) as it is one of the well-established 'Interactionism' frameworks used to consider constructs which have significant impact on IS innovation and adoption. The TOE framework can help explain the interrelationships between different constructs in one dynamic framework (Boateng et al. 2009, Molla and Licker 2005b), whether internal or external to an organisation (Jarvenpaa and Leidner 1998, Montealegre 1999). In addition, it suggests why certain kinds of innovations are more successful in a given organisation then others (Molla and Licker 2005b).

The TOE framework posits three perspectives - technological $(\mathrm{T})$, organisational $(\mathrm{O})$ and environmental $(\mathrm{E})$ - which are used in this study to determine the discriminating factors of $\mathrm{E}$ commerce adoption. Technological context relates to perceived technological benefits around compatibility, relative advantage, ease of use, cost and 'trialability'. Organisational context relates to the attitudes of managers toward the innovation, their involvement and support, organisations' attributes (e.g. size, centralization, formalisation), the quality of human resources, the complexity of management structures and the amount of spare internal resource available (Tornatzky and Fleischer 1990). The environmental context (or macro arena) focuses on external influences and relates to the industrial context; which includes pressure from competitors and social trends, accessibility and readiness of resources provided by regulatory policies, economic and technological infrastructure. The interrelationships between these three perspectives can help discriminate successful adopters from unsuccessful non-adopters (Boateng et al. 2009).

The TOE framework and derivations of it have been successfully used in the past for organisational level E-commerce adoption studies. For example, Tan et al. (2003) introduced

\footnotetext{
${ }^{3}$ Known also by organisational innovation theory
} 
a model called the "Model of Small Business E-Marketplace Adoption" and is grounded on the TOE framework. In addition, other studies (Lertwongsatien and Wongpinunwatana 2003, Molla and Licker 2005a, 2005b, Soliman and Janz 2004, Tan et al. 2007) have used similar models based on innovation, organisational, and environmental factors to explain differences in e-commerce adoption.

Using this approach in developing countries has been proved to be useful recently. For example Wanyoike, et al. (2012) conducted studies in Kenya. Ghobakhloo, et al. (2011) and Gilaninia et al. (2011) conducted studies in Iran. Chiliya et al. (2011) and Molla and Licker (2005a, 2005b) conducted studies in South Africa. Cui et al. (2006) and Tan et al. (2007) conducted studies in China. Wang and Tsai (2009), Lin and Lee (2005), Thatcher et al. (2006) and Chiu et al. (2014) conducted studies in Taiwan. Kendall et al. (2001) and Kheng and Al-Hawamdeh (2002) conducted studies in Singapore. Ang et al. (2003) conducted a study in Malaysia. Seyal et al. (2004) conducted a study in Pakistan. Tarafdar and Vaidya (2004, 2006) conducted studies in India, and Kaynak et al. (2005) conducted a study in Turkey. All of these studies have given useful findings about E-commerce adoption in different national and cultural contexts (see table 3). However, the adoption of E-commerce in Arab world remains an under researched area (Alrawi and Sabry, 2009, Aladwani 2003), especially where detailed stages and an inclusive number of constructs are considered in a large scale survey, as in this study (Waarts et al. 2002). This study also examines the interactions of constructs that influence E-commerce adoption failure or success and differentiates early and late adopters.

\subsection{A New Stage Orientated Model (SOM) for E-commerce Adoption}

E-commerce adoption in organisations is a developmental process in which organisations are found to follow a relatively predictable pattern of development through a number of stages (Cooper and Zmud 1990, Rogers 1995, Zaltman et al 1973). Moreover, studies have suggested numerous models to classify stages of the adoption process of an innovation. For example, Cooper and Zmud (1990) regarded IT implementation as a technological innovation diffusion process and proposed a six-staged model while Molla and Licker (2005a, 2005b) proposed a two-stage model of E-commerce adoption. 
Table 3: Review of prior literature on e-commerce adoption in developing countries

\begin{tabular}{|c|c|c|c|}
\hline Source & Methodology used & Explanatory Variables & Major findings \\
\hline $\begin{array}{l}\text { Wanyoike, et al. } \\
(2012)\end{array}$ & $\begin{array}{l}\text { Survey } \\
\text { questionnaire } \\
(\mathrm{n}=400), \quad \text { small } \\
\text { enterprises located } \\
\text { in four main urban } \\
\text { towns } \\
\text { of Kenya }\end{array}$ & $\begin{array}{l}\text { - IV: Relative advantage, Compatibility, } \\
\text { Complexity, Trialability, Observability } \\
\text { - DV: B2B e-commerce adoption }\end{array}$ & $\begin{array}{l}\text { - Small formal enterprises in urban Kenya are } \\
\text { influenced to adopt e-commerce by being able to } \\
\text { observe visible results emanating from its use such } \\
\text { as simplification of work routines, efficient } \\
\text { coordination among various value chain partners, } \\
\text { increased productivity and improved customers } \\
\text { services that leads to customer satisfaction. }\end{array}$ \\
\hline $\begin{array}{l}\text { Chiliya et } \quad \text { al. } \\
\text { (2011) }\end{array}$ & $\begin{array}{l}\text { Face-to-face and } \\
\text { Telephone in-depth } \\
\text { interviews } \quad 50 \\
\text { adopters and } \\
25 \text { non-adopters of } \\
\text { e-commerce), } \\
\text { SMEs in the } \\
\text { Eastern rape } \\
\text { Province, South } \\
\text { Africa }\end{array}$ & $\begin{array}{l}\text { - IV: Incentives (customer care, competitive edge, } \\
\text { cost, prestige, customer loyalty, information } \\
\text { exchange, service niche markets, new investors, } \\
\text { international market access ) } \\
\text { - Impediments (Lack of training, government } \\
\text { support, lack of IT knowledge among staff, } \\
\text { Security, acquiring of e-business, infrastructure, size, } \\
\text { low penalties against hackers, insufficient internal } \\
\text { resources, complexity of e-business, uncertainty, } \\
\text { type of business, little perceiving incentives, staff } \\
\text { resistance, level of IT investment, gender, age of the } \\
\text { owner, firm vision, firm age and level of } \\
\text { qualification) } \\
\text { - DV: Adoption of e-commerce }\end{array}$ & $\begin{array}{l}\text { - The most significant e-business adoption variables } \\
\text { in the province are security, prestige, government } \\
\text { support, vision and the need to service niche } \\
\text { markets. } \\
\text { - Level of educational qualification is not } \\
\text { significant which means that in the Eastern Cape } \\
\text { Province education level of the SME owner (or } \\
\text { manager) does not influence the adoption of e- } \\
\text { commerce. }\end{array}$ \\
\hline $\begin{array}{l}\text { Ghobakhloo, et al. } \\
\text { (2011) }\end{array}$ & $\begin{array}{l}\text { Survey } \\
\text { questionnaire } \\
(\mathrm{n}=235), \\
\text { manufacturing } \\
\text { SMEs in Iran. }\end{array}$ & $\begin{array}{l}\text { - IV: Perceived compatibility, Perceived relative } \\
\text { advantage, cost, Information intensity, CEO s IS } \\
\text { knowledge, CEO's innovativeness, Business size, } \\
\text { Competition, Buyer/supplier pressure, Support from } \\
\text { technology } \\
\text { vendors } \\
\text { - DV: e-commerce adoption }\end{array}$ & $\begin{array}{l}\text { - EC adoption within SMEs is affected by } \\
\text { perceived relative advantage, perceived } \\
\text { compatibility, CEO's innovativeness, information } \\
\text { intensity, buyer/supplier pressure, support from } \\
\text { technology vendors, and competition. }\end{array}$ \\
\hline
\end{tabular}




\begin{tabular}{|c|c|c|c|}
\hline Source & Methodology used & Explanatory Variables & Major findings \\
\hline $\begin{array}{l}\text { Gilaninia et al. } \\
\text { (2011) }\end{array}$ & $\begin{array}{l}\text { Survey } \\
\text { questionnaire } \\
\text { (n=956), SMEs in } \\
\text { Iran (Ardabil) }\end{array}$ & $\begin{array}{l}\text { - IV: organizational Factors, electronic Commerce } \\
\text { benefits, e-commerce risks, compatibility and } \\
\text { perceived ease of use. } \\
\text { - DV: The acceptance of e-commerce in co- } \\
\text { operative-enterprise }\end{array}$ & $\begin{array}{l}\text { - Organizational factors variable, perceived ease } \\
\text { of use, compatibility are significant predictors for } \\
\text { the adoption of e-commerce. } \\
\text { - Electronic commerce risks variable is significant } \\
\text { predictor for the acceptance of electronic } \\
\text { commerce. }\end{array}$ \\
\hline Tan et al., 2007 & $\begin{array}{l}\text { cross-sectional } \\
\text { survey } \quad(n=134) \\
\text { SMEs in china }\end{array}$ & $\begin{array}{l}\text { - DV: E-commerce adoption } \\
\text { - IV: Perceived organizational or internal } \\
\text { eReadiness (POER) and Perceived external or } \\
\text { environmental eReadiness (PEER) }\end{array}$ & $\begin{array}{l}\text { - External environment eReadiness plays major role } \\
\text { in e-commerce adoption while the internal } \\
\text { organizational factors are inhibiting e-commerce } \\
\text { adoption and diffusion in china. } \\
\text {-Firms in China suffer from a lack of business } \\
\text { and human resources, in terms of firm size, and } \\
\text { resources available for employees to pursue } \\
\text { innovation. }\end{array}$ \\
\hline $\begin{array}{l}\text { Tarafdar and } \\
\text { Vaidya (2006) }\end{array}$ & $\begin{array}{l}\text { Multiple case study } \\
\text { design (Four firms } \\
\text { from the financial } \\
\text { services industry in } \\
\text { India) } \\
\end{array}$ & $\begin{array}{l}\text { - IV: Leadership characteristics, organizational } \\
\text { characteristics, Characteristics of Information } \\
\text { Systems (IS) professionals, f organization structure } \\
\text { - DV: Inclination for adopting e-commerce }\end{array}$ & $\begin{array}{l}\text { - Leadership characteristics, organizational } \\
\text { characteristics, characteristics of information } \\
\text { systems Professionals and Organization Structure } \\
\text { influence organizational inclination towards } \\
\text { deploying e-commerce technologies. }\end{array}$ \\
\hline Lin and Lee (2005) & $\begin{array}{l}\text { Survey } \\
\text { questionnaire } \\
(\mathrm{n}=202), \text { Large } \\
\text { firms from various } \\
\text { industries in } \\
\text { Taiwan }\end{array}$ & $\begin{array}{l}\text { - IV: Organisational learning factors (training } \\
\text { available, technical expertise, and knowledge } \\
\text { level) and knowledge management process } \\
\text { (knowledge acquisition, knowledge application, } \\
\text { and knowledge sharing) } \\
\text { - DV: E-business systems adoption level. }\end{array}$ & $\begin{array}{l}\text { - Organisational learning and knowledge } \\
\text { management processes are closely related to the } \\
\text { level of e-business systems adoption. } \\
\text { - Firms with greater levels of technical expertise } \\
\text { and e-business knowledge attain higher levels of e- } \\
\text { business systems adoption. }\end{array}$ \\
\hline $\begin{array}{l}\text { Kendall et } a l . \\
(2001)\end{array}$ & $\begin{array}{l}\text { Survey } \\
\text { questionnaire }(\mathrm{n}= \\
58) \text { SMEs in } \\
\text { Singapore }\end{array}$ & $\begin{array}{l}\text { - IV: The five attributes of innovation highlighted } \\
\text { by Rogers (Relative advantage, Compatibility, } \\
\text { Complexity, Trialability, Observability) } \\
\text { - DV: Willingness to adopt e-commerce }\end{array}$ & $\begin{array}{l}\text { - Only relative advantage, compatibility and } \\
\text { trialability appear significant for the willingness to } \\
\text { adopt e-commerce. }\end{array}$ \\
\hline
\end{tabular}


This study contributes to the existing literature by investigating the constructs which might impact on the adoption of E-commerce by organisations in Saudi Arabia. This study does this by developing a specific Stage-Oriented Model (SOM). This is because organisations may differ in their level of E-commerce adoption, varying from the very simple use of E-mail to more complex collaborative platforms used to deliver services to employees, partners and customers. The TOE framework was the bases for the stage-oriented model used in this study.

Thus we proposed three stages to the E-commerce adoption process in an organisation which is consistent with previous research. We refer to the first stage as 'Non-Interactive Ecommerce' adoption and the second as 'Interactive E-commerce' adoption and the third as the 'Stabilised E-commerce' adoption.

The Non-Interactive or initiation stage of E-commerce adoption refers to the decision to invest in E-commerce and the preparation for redesigning business activities that lead to a choice to adopt or reject the innovation (Rogers 1995). Organisations use the Internet as a bulletin board for brochures, employee telephone directories, and for other documents such as catalogues and price lists (Hartman et al. 2000). Generally speaking, the early stages of Ecommerce adoption are typified by a simple, static informational or non-interactive website containing basic information about the organisation's products and services.

The Interactive adoption stage is where organisations make the first attempt to utilize Ecommerce technology and try to establish an interactive web presence by establishing twoway communications or interactions with users. Previous research has considered interactive E-commerce as the beginning of the E-commerce adoption process (Molla and Licker 2005a, 2005b).

Finally, Stabilisation of E-commerce occurs when technology has become incorporated into the organisation's core activities (i.e. products selling, orders tracking, relationship management) and organisational members become experienced E-commerce users (Molla and Licker 2005a). The Stage Oriented Model incorporating both TOE constructs and the staged adoption process as discussed above was proposed specifically to investigate Ecommerce adoption by Saudi Arabian organisations; it is presented in Figure 1 and is a new original framework previously unpublished. 


\section{E-commerce Technology Characteristics \\ - Relative Advantage $\left(\mathrm{H}_{1.1}, \mathrm{H}_{1.2}, \mathrm{H}_{1.3}\right)$ \\ - Compatibility $\left(\mathrm{H}_{2.1}, \mathrm{H}_{2.2}, \mathrm{H}_{2.3}\right)$ \\ - $\operatorname{Cost}\left(\mathrm{H}_{3.1}, \mathrm{H}_{3.2}, \mathrm{H}_{3.3}\right)$ \\ - Security Concern $\left(\mathrm{H}_{4.1}, \mathrm{H}_{4.2}, \mathrm{H}_{4.3}\right)$ \\ - Language Barrier $\left(\mathrm{H}_{5.1}, \mathrm{H}_{5.2}, \mathrm{H}_{5.3}\right)$}

\section{Organisational Context}

- IT readiness $\left(\mathrm{H}_{6.1}, \mathrm{H}_{6.2}, \mathrm{H}_{6.3}\right)$

- Management team support $\left(\mathrm{H}_{7.1}, \mathrm{H}_{7.2}, \mathrm{H}_{7.3}\right)$

- Learning orientation $\left(\mathrm{H}_{8.1}, \mathrm{H}_{8.2}, \mathrm{H}_{8.3}\right)$

- Receptivity toward change $\left(\mathrm{H}_{9.1}, \mathrm{H}_{9.2}, \mathrm{H}_{9.3}\right)$

- Strategic orientation $\left(\mathrm{H}_{10.1}, \mathrm{H}_{10.2}, \mathrm{H}_{10.3}\right)$

- Formalization level $\left(\mathrm{H}_{11.1}, \mathrm{H}_{11.2}, \mathrm{H}_{11.3}\right)$

- Decentralization Level $\left(\mathrm{H}_{12.1}, \mathrm{H}_{12.2}, \mathrm{H}_{12.3}\right)$

\section{Environmental Context}

- Market force influence $\left(\mathrm{H}_{13.1}, \mathrm{H}_{13.2}, \mathrm{H}_{13.3}\right)$

- Economic downturn influence $\left(\mathrm{H}_{14.1}, \mathrm{H}_{14.2}, \mathrm{H}_{14.3}\right)$

- Competitive pressure $\left(\mathrm{H}_{15.1}, \mathrm{H}_{15.2}, \mathrm{H}_{15.3}\right)$

- Regulatory \& legal environment $\left(\mathrm{H}_{16.1}, \mathrm{H}_{16.2}, \mathrm{H}_{16.3}\right)$

- National e-readiness $\left(\mathrm{H}_{17.1}, \mathrm{H}_{17.2}, \mathrm{H}_{17.3}\right)$

- Technology consultants' participation $\left(\mathrm{H}_{18.1}, \mathrm{H}_{18.2}, \mathrm{H}_{18.3}\right)$

\subsection{Hypotheses Development}

The following hypotheses (Table 4) were proposed based on the stage-oriented model presented in Figure 1. 


\begin{tabular}{|c|c|}
\hline Research Hypotheses & $\begin{array}{c}\text { Anticipated } \\
\text { directions }\end{array}$ \\
\hline $\begin{array}{l}\mathbf{H}_{1.1}, \mathbf{H}_{1.2}, \mathbf{H}_{1.3} \text { : Relative advantage contributes significantly (and is positively related) to } \\
\text { the Non-Interactive adoption, Interactive adoption and Stabilisation of E-commerce. }\end{array}$ & + \\
\hline $\begin{array}{l}\mathbf{H}_{2.1}, \mathbf{H}_{2.2}, \mathbf{H}_{2.3} \text { : Compatibility contributes significantly (and is positively related) to the } \\
\text { Non-Interactive adoption, Interactive adoption and Stabilisation of E-commerce. }\end{array}$ & + \\
\hline $\begin{array}{l}\mathbf{H}_{3.1}, \mathbf{H}_{3.2}, \mathbf{H}_{3.3} \text { : Cost contributes significantly (and is negatively related) to the Non- } \\
\text { Interactive adoption, preliminary Interactive adoption and Stabilisation of E-commerce. }\end{array}$ & - \\
\hline $\begin{array}{l}\mathbf{H}_{4.1}, \mathbf{H}_{4.2}, \mathbf{H}_{4.3} \text { : Security concern contributes significantly (and is negatively related) to the } \\
\text { Non-Interactive adoption, Interactive adoption and Stabilisation of E-commerce. }\end{array}$ & - \\
\hline $\begin{array}{l}\mathbf{H}_{5.1}, \mathbf{H}_{5.2}, \mathbf{H}_{5.3} \text { : Language barrier contributes significantly (and is negatively related) to the } \\
\text { Non-Interactive adoption, Interactive adoption and Stabilisation of E-commerce. }\end{array}$ & - \\
\hline $\begin{array}{l}\mathbf{H}_{6.1}, \mathbf{H}_{6.2}, \mathbf{H}_{6.3} \text { : Information technology (IT) readiness contributes significantly (and is } \\
\text { positively related) to the Non-Interactive adoption, Interactive adoption and Stabilisation of E- } \\
\text { commerce. }\end{array}$ & + \\
\hline $\begin{array}{l}\mathbf{H}_{7.1}, \mathbf{H}_{7.2}, \mathbf{H}_{7.3}: \text { Management team support contributes significantly (and is positively } \\
\text { related) to the Non-Interactive adoption, Interactive adoption and Stabilisation of E- } \\
\text { commerce. }\end{array}$ & + \\
\hline $\begin{array}{l}\mathbf{H}_{\mathbf{8 . 1}}, \mathbf{H}_{\mathbf{8} .2}, \mathbf{H}_{\mathbf{8} .3}: \text { Organisational learning orientation contributes significantly (and is } \\
\text { positively related) to the Non-Interactive adoption, Interactive adoption and Stabilisation of E- } \\
\text { commerce. }\end{array}$ & + \\
\hline $\begin{array}{l}\mathbf{H}_{9.1}, \mathbf{H}_{9.2}, \mathbf{H}_{9.3} \text { : Receptivity toward change contributes significantly (and is positively } \\
\text { related) to the Non-Interactive adoption, Interactive adoption and Stabilisation of E- } \\
\text { commerce. }\end{array}$ & + \\
\hline $\begin{array}{l}\mathbf{H}_{10.1}, \mathbf{H}_{10.2}, \mathbf{H}_{10.3} \text { : Strategic orientation contributes significantly (and is positively related) } \\
\text { to the Non-Interactive adoption, Interactive adoption and Stabilisation of E-commerce. }\end{array}$ & + \\
\hline $\begin{array}{l}\mathrm{H}_{11.1}, \mathrm{H}_{11.2}, \mathrm{H}_{11.3} \text { : The formalization level of organisations contributes significantly (and is } \\
\text { positively related) to the Non-Interactive adoption, Interactive adoption and Stabilisation of E- } \\
\text { commerce. }\end{array}$ & + \\
\hline $\begin{array}{l}\mathbf{H}_{12.1}, \mathbf{H}_{12.2}, \mathbf{H}_{12.3} \text { : The decentralization level of organisations contributes significantly (and } \\
\text { is positively related) to the Initiation, Interactive adoption and Stabilisation of E-commerce. }\end{array}$ & + \\
\hline $\begin{array}{l}\mathrm{H}_{13.1}, \mathbf{H}_{13.2}, \mathbf{H}_{13.3} \text { : Market force influence contributes significantly (and is positively } \\
\text { related) to Non-Interactive adoption, Interactive adoption and the Stabilisation of E- } \\
\text { commerce. }\end{array}$ & + \\
\hline $\begin{array}{l}\mathbf{H}_{\mathbf{1 4 . 1}}, \mathbf{H}_{\mathbf{1 4 . 2}}, \mathbf{H}_{\mathbf{1 4 . 3}}: \text { Economic downtown contributes significantly (and is negatively } \\
\text { related) to the Non-interactive adoption, Interactive adoption and Stabilisation of E- } \\
\text { commerce. }\end{array}$ & - \\
\hline $\begin{array}{l}\mathrm{H}_{15.1}, \mathbf{H}_{15.2}, \mathbf{H}_{15.3} \text { : Competitive pressure contributes significantly (and is positively related) } \\
\text { to the Non-Interactive adoption, Interactive adoption and the Stabilisation of E-commerce. }\end{array}$ & + \\
\hline $\begin{array}{l}\mathrm{H}_{16.1}, \mathrm{H}_{16.2}, \mathrm{H}_{16.3} \text { : The existence of regulatory environment contributes significantly (and } \\
\text { is positively related) to Non-Interactive adoption, Interactive adoption and Stabilisation of E- } \\
\text { commerce. }\end{array}$ & + \\
\hline $\begin{array}{l}\mathbf{H}_{17.1}, \mathbf{H}_{17.2}, \mathbf{H}_{17.3} \text { : National E-readiness contributes significantly (and is positively related) } \\
\text { to Non-Interactive adoption, Interactive adoption and Stabilisation of E-commerce. }\end{array}$ & + \\
\hline $\begin{array}{l}\mathbf{H}_{18.1}, \mathbf{H}_{18.2}, \mathbf{H}_{18.3}: \text { Technology consultants' participation contributes significantly (and is } \\
\text { positively related) to the Non-Interactive adoption, Interactive adoption and Stabilisation of E- } \\
\text { commerce. }\end{array}$ & + \\
\hline
\end{tabular}




\section{Research Methodology}

In order to empirically test the research hypotheses, a survey method was used. Initial versions of the survey were pilot tested with experts (academics, consultants and managers) and revised accordingly. The English version was translated into Arabic using Brislin's (1986) back translation method and repeated until both versions converged. All independent constructs were measured on a Likert five-point scale, from 1 ("strongly disagree") to 5 ("strongly agree") enabling respondents characterise their organisation. The dependent variable, namely E-commerce adoption, was measured as a dichotomous variable within three groups, i.e., adopters of Non-Interactive E-commerce, adopters of Interactive Ecommerce, and advanced adopters. The final items used to measure each construct are presented in appendix A.

\subsection{Research sample}

A questionnaire was distributed to 450 organisations selected using systematic random sampling technique from the Saudi Chamber of Commerce and Industry database which has been established for over 30 years. The final usable number of responses was 202, which compares favourably with other studies (e.g. Grandon and Pearson 2004, Thong et al. 1996). The profile of organisations is illustrated in Table 5 showing 54.5\% manufacturing companies and $45.5 \%$ service companies; $32.7 \%$ small and medium-sized enterprises (SMEs) with fewer than 100 employees and $67.3 \%$ larger enterprises with greater than 100 employees. Individual respondents were $90.1 \%$ male and $9.9 \%$ female respondents (this is not unusual in the work environment in SA, where women are not allowed to work in any job that exposes them to contact with men).

Questionnaires were addressed personally to those key decision makers who had a high management status, such as managing director or direct manager, as they are seen as having a wide breadth of knowledge of all of the organisation's activities, are involved in decisions leading to the adoption of technology in their business settings, and can provide an overall assessment of the key challenges and concerns of using e-commerce. The characteristics of the sample indicate that an over-whelming majority (65\%) of the respondents were managing directors, CEOs or IS managers, were generally well educated with over $62 \%$ having a University degree and $65 \%$ belonged to the 30 to 49 year old age group. The majority of respondents were from construction, banking, finance and insurance entities, representing 
$15 \%$ of the sample. Finally, the majority of the firms sampled (70.8\%) had been established for more than 10 years, while a mere $16.8 \%$ had only been established for less than 5 years. 


\section{Table 5. Sample Description}

\begin{tabular}{|c|c|c|}
\hline Variables & Frequencies & Percentage \% \\
\hline \multicolumn{3}{|l|}{ Position of the respondent } \\
\hline President, Managing Director, CEO & 83 & 41.1 \\
\hline Information Services (IS) Manager, Director, Planner & 49 & 24.3 \\
\hline Business Operations Manager, COO & 35 & 17.3 \\
\hline Administration/Finance Manager, CFO & 35 & 17.3 \\
\hline \multicolumn{3}{|l|}{ Gender of the respondent } \\
\hline \begin{tabular}{l|l} 
& Male \\
\end{tabular} & 182 & 90.1 \\
\hline Female & 19 & 9.4 \\
\hline Missing & 1 & 0.5 \\
\hline \multicolumn{3}{|l|}{ Age of the of the respondent } \\
\hline \begin{tabular}{|l|l} 
& $21-29 \mathrm{yrs}$ \\
\end{tabular} & 45 & 22.3 \\
\hline $30-39$ yrs & 68 & 33.7 \\
\hline $40-49$ yrs & 61 & 30.2 \\
\hline $50-59 \mathrm{yrs}$ & 24 & 11.9 \\
\hline 60 or older & 2 & 1 \\
\hline Missing & 2 & 1 \\
\hline \multicolumn{3}{|l|}{ Education of the of the respondent } \\
\hline Less than High School & 3 & 1.5 \\
\hline High School & 20 & 9.9 \\
\hline Trade qualifications & 6 & 3.0 \\
\hline Diploma & 6 & 3.0 \\
\hline Bachelor's & 125 & 61.9 \\
\hline Master's & 36 & 17.8 \\
\hline Doctoral & 6 & 3.0 \\
\hline \multicolumn{3}{|l|}{ Firm size } \\
\hline 1- 9 employees & 19 & 9.4 \\
\hline $10-25$ employees & 19 & 9.4 \\
\hline $26-100$ employees & 28 & 13.9 \\
\hline 101-200 employees & 36 & 17.8 \\
\hline $201-250$ employees & 10 & 5.0 \\
\hline 251- 500 employees & 15 & 7.4 \\
\hline $501-1,000$ employees & 19 & 9.4 \\
\hline $1,001-2,500$ employees & 16 & 7.9 \\
\hline More than 2,500 employees & 40 & 19.8 \\
\hline \multicolumn{3}{|l|}{ Industry } \\
\hline Construction and building (manufacturing) & 30 & 14.9 \\
\hline Insurance and financial services & 30 & 14.9 \\
\hline Computer and electronic products (manufacturing) & 28 & 13.9 \\
\hline Electrical materials and accessories (manufacturing) & 19 & 9.4 \\
\hline Food and beverages (manufacturing) & 12 & 5.9 \\
\hline Motors and autos (manufacturing) & 12 & 5.9 \\
\hline Medical care & 12 & 5.9 \\
\hline Textiles and clothing (manufacturing) & 11 & 5.4 \\
\hline Transportation (Air and Ground) & 10 & 5 \\
\hline Maintenance and Cleaning Services & 9 & 4.5 \\
\hline Marketing and Advertising & 7 & 3.5 \\
\hline Tourism and Hospitality Services & 7 & 3.5 \\
\hline Furniture (manufacturing) & 6 & 3 \\
\hline Training and consultancy & 5 & 2.5 \\
\hline Publishing and Printing (manufacturing) & 4 & 2 \\
\hline \multicolumn{3}{|l|}{ Used e-commerce technologies } \\
\hline Connected to the Internet with e-mail but no web site. & 40 & 19.8 \\
\hline Static Web without any interactivity. & 34 & 16.8 \\
\hline Interactive web presence. & 66 & 32.7 \\
\hline $\begin{array}{l}\text { Transactive web that allows online selling and purchasing } \\
\text { of products and services. }\end{array}$ & 13 & 6.4 \\
\hline $\begin{array}{l}\text { Integrated web in which most of the business transactions } \\
\text { are conducted electronically (i.e. inventory update, } \\
\text { electronic paperwork and receipts). }\end{array}$ & 49 & 24.3 \\
\hline
\end{tabular}

Note: 122 companies (54.5\% of sample) from manufacturing based companies 
Table 5 further shows that $24.3 \%$ of the organisations allowed business activities to be conducted through the Internet and use the Internet as part of their strategy to develop Emarkets. This is followed by $19.8 \%$ of the sample who claimed to be using Email communication in their operations but did not have website. Furthermore, $16.8 \%$ of the firms have a static website that only provides information about products or services without any interactivity. $6.4 \%$ of firms provided online buying and E-payment. Also it was notable that there were not any companies without online capabilities (i.e. Internet access or Email).

Three classification groups, as illustrated in Figure 2, were established for E-commerce adoption, which was adapted from Cooper and Zmud's (1990) six stage model. (1) those who used the Internet and had Email access or a static website presence were placed in the 'NonInteractive' phase (2) those who had established an interactive website presence were placed in the 'Interactive adoption' phase and (3) those with a full transactional web presence and integrated web status were placed in the 'Stabilisation' phase. Also, a proportion of respondents in each industry category was compared with the overall sample and a Chisquare test was performed to examine the presence of response bias of respondents by industry which was not significant (at $\alpha=0.05$ ) indicating that there was no significant response bias among respondents from different industries.

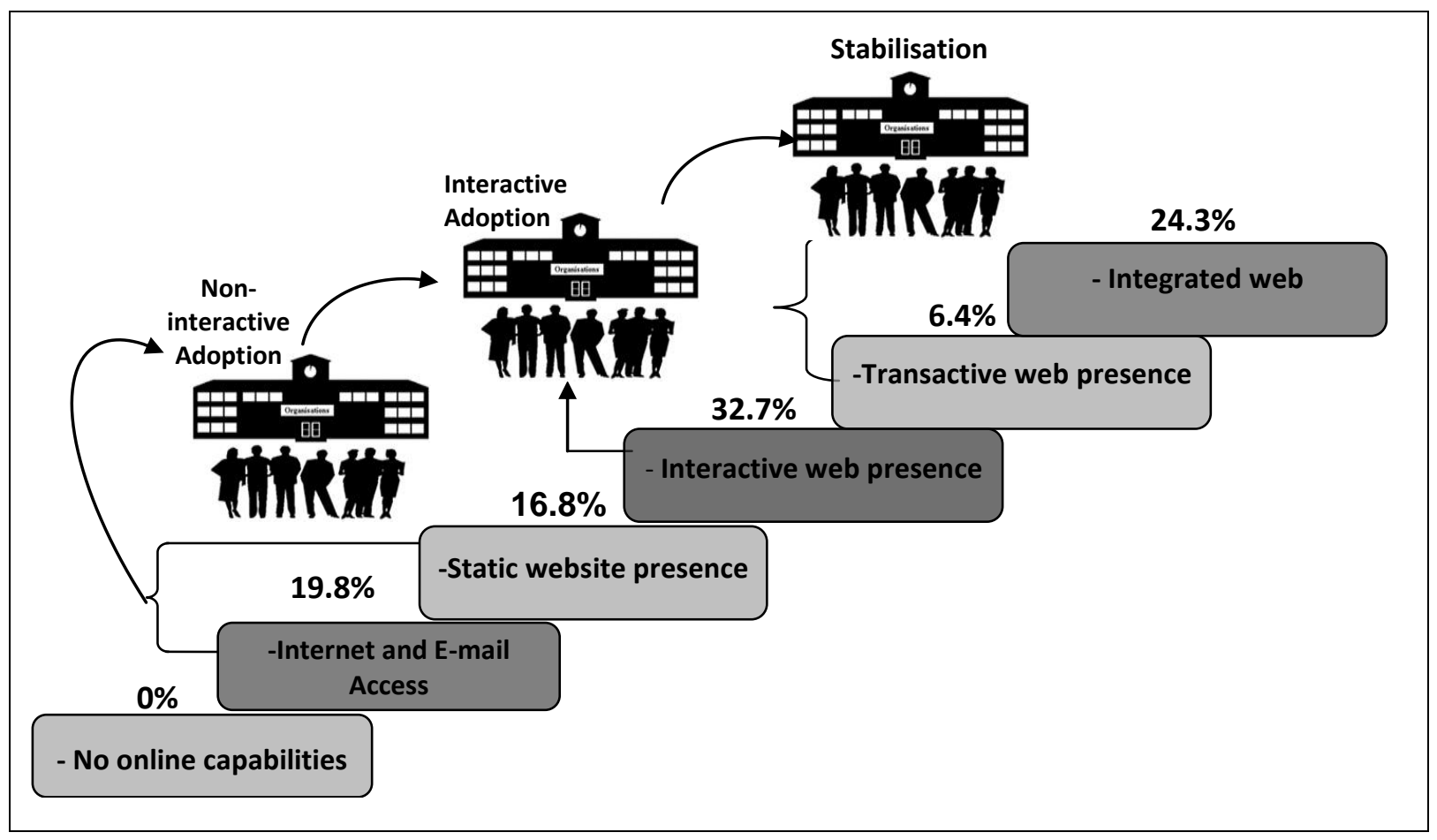

Figure 2. Organisations Level of E-commerce Adoption 


\subsection{Testing the Measurement Model}

Construct validity and reliability assessments were conducted to determine the extent to which a particular item (measures) represents a given theoretical concept (construct) and to ensure that data are rigorous and robust.

\subsubsection{Initial Reliability Test}

To test the reliability of each item, we computed the coefficient alpha and item-to-total correlations. The corrected item-to-total correlations were plotted in descending order, and items were excluded if they had a correlation close to zero $(<0.35)$ (Churchill, 1979). The threshold value was appropriate, as it gave correlations significant to less than $1 \%$. Moreover, this cut-off was comparable to those used by previous researchers (Molla and Licker 2005a, Tan et al. 2007). The following items were found deficient and were dropped:

- Four items from technology context (COS4, SEC3, SEC4 and LAB2)

- One item from organisational context (RTC6), and

- Three items from environmental context (MRF3, MRF 7, and CMT5)

All the remaining items performed well and were shown to be adequate measures of the constructs. The corrected item-to-total correlations were significant at $\mathrm{p}=0.05$ and values ranged from 0.37 to 0.74 .

\subsubsection{Validity Test}

Construct validity focuses on the extent to which a particular item (measure) relates to other items are consistent with the theoretically derived hypotheses which may be determined in terms of convergent and discriminant validities. While convergent validity evaluates whether all the items measuring a construct cluster together to form a single construct, discriminant validity measures the degree to which a construct differs from other constructs - indicated by low correlation with those theoretically different (Churchill 1979, Kerlinger 1986). Factor analysis can be used to assess both convergent and discriminant validities; separate factor analyses were performed on the technological, organisational and environmental variables to ensure the stability of the factor loadings of various constructs. Moreover, separate factor analysis is done to ensure that the ratio of variable items to the sample size was maintained at 1:10 (ten subjects for each variable). This statistical rule of thumb, suggested by Kerlinger 
(1986), has been used successfully in other studies (Kheng and Al-Hawamdeh 2002, Teo et al. 1998).

For factor analysis, items were retained based on the following criteria (1) dropping items with a factor loading less than 0.5 on all factors from subsequent iterations (2) subsequently dropping items with a factor loading greater than 0.5 on two or more factors (Tarafdar and Vaidya 2006). In general, both convergent and discriminant validities were satisfied as the items measuring each construct clustered from distinct factors and there were no crossloading of items. However, one item (DEL1) from the organizational context was found deficient and were dropped because it has factor loading less than 0.5 .

To determine reliability, Cronbach's alpha was computed for each variable. A value of 0.7 in the Cronbach's alpha is considered adequate to ensure reliability of the internal consistency of the questionnaire (Nunnally, 1978). However, Hair et al. (1995) argued that Cronbach's alpha may decrease to 0.60 in exploratory research. Cronbach alpha scores ranged from 0.582 to 0.945 . Since the lowest scores fairly close to 0.60 , all the constructs are deemed to have adequate reliability. Pearson correlations for the constructs are below the threshold value of 0.80 and do not suggest any obvious problem of item multi-collinearity (Hair et al. 1995). 


\section{Testing the Structural Model}

Multiple discriminant function analysis (MDFA) was conducted to test the research model and the proposed hypotheses. MDFA is used to predict membership in two or more groups with respect to two or more independent variables simultaneously. Moreover, it is an appropriate technique when the dependent variable is categorical (either dichotomous or multi-chotomous) and the independent variable is interval (Hair et al. 1995). Discriminant loading (a.k.a structure correlation) measuring the simple linear correlation between each predictor variable and the extracted discriminant function is used to determine the significance of the variables. Independent variables (constructs) with factor loadings greater than or equal to \pm 0.30 were identified as significant contributors to the discriminant power of the function at $\mathrm{p}<0.10$ (Hair et al. 1995). By analysing the data missing values were eliminated and a $5 \%(\alpha=0.05)$ significance level was maintained. Three separate models were generated for the three groups of E-commerce adoption: Non-Interactive adoption, Interactive adoption and Stabilisation.

\subsection{Non-Interactive E-commerce Adoption}

Non-Interactive E-commerce adoption was evaluated only for organisations that used the Internet with Email communication as well as organisations that used a static website without any interactivity. The results of the discriminant analysis together with the descriptive statistics are presented in Table 6 The model for 'Non-Interactive E-commerce' adoption was statistically significant at $\mathrm{p}<0.002$ with a value of Wilks' Lambda $(\lambda)$ of $0.815\left(\chi^{2}=39.128\right.$, $\mathrm{df}=17)$. The function correctly classifies $64.3 \%$ of the organisations in the sample $(60.8 \%$ of the Non-Interactive adopters and $68.2 \%$ of the Interactive adopters).

To determine the relative importance of each independent variable (constructs) and discriminate between the groups, the discriminant loadings and the probabilities for the $f$ statistics were examined. The independent variables that were most significant to the discriminant function were in descending order: technology consultant's participation, regulatory and legal environment, management team support, IT readiness, trading partner pressure, strategic orientation, learning orientation and economic downturn. Therefore, the results fully support $\mathrm{H}_{6.1}, \mathrm{H}_{7.1}, \mathrm{H}_{8.1}, \mathrm{H}_{10.1}, \mathrm{H}_{13.1}, \mathrm{H}_{14.1}, \mathrm{H}_{16.1}$, and $\mathrm{H}_{18.1}$ (c.f. Table 4 for hypothesis definition). 
Table 6. Discriminant Analysis for Non-Interactive E-commerce Adoption

\begin{tabular}{|c|c|c|c|c|c|}
\hline Construct & $\begin{array}{l}\text { Wilks' } \\
\text { Lambda }\end{array}$ & $\begin{array}{l}\text { Univariate } \mathbf{F} \\
\text { ratio (Sig.) }\end{array}$ & P (Sig.) & $\begin{array}{l}\text { Discriminant } \\
\text { loadings }\end{array}$ & $\begin{array}{l}\text { Discriminant } \\
\text { Coefficient }\end{array}$ \\
\hline \multicolumn{6}{|c|}{ E-commerce Technology Characteristics } \\
\hline $\mathrm{H}_{1.1}$ Relative advantage & 0.987 & 2.615 & 0.107 & 0.239 & 0.027 \\
\hline $\mathrm{H}_{2.1}$ Compatibility & 0.999 & 0.226 & 0.635 & 0.070 & 0.101 \\
\hline $\mathrm{H}_{3.1} \mathrm{Cost}$ & 0.985 & 3.097 & 0.080 & -0.260 & -0.019 \\
\hline $\mathrm{H}_{4.1}$ Security Concern & 0.985 & 2.975 & 0.086 & -0.255 & -0.232 \\
\hline $\mathrm{H}_{5.1}$ Language Barrier & 1.000 & 0.011 & 0.917 & -0.015 & -0.047 \\
\hline \multicolumn{6}{|l|}{ Organisational Context } \\
\hline $\mathrm{H}_{6.1}$ IT readiness & 0.963 & 7.698 & 0.006 & 0.410 & 0.373 \\
\hline $\begin{array}{l}\mathrm{H}_{7.1} \text { Management team } \\
\text { support }\end{array}$ & 0.957 & 8.940 & 0.003 & 0.442 & 0.190 \\
\hline $\mathrm{H}_{8.1}$ learning orientation & 0.976 & 4.856 & 0.029 & 0.326 & 0.016 \\
\hline $\begin{array}{l}\mathrm{H}_{9.1} \text { Receptivity toward } \\
\text { change }\end{array}$ & 0.985 & 3.024 & 0.084 & 0.257 & 0.043 \\
\hline $\mathrm{H}_{10.1}$ Strategic orientation & 0.976 & 4.912 & 0.028 & 0.327 & 0.118 \\
\hline $\mathrm{H}_{11.1}$ Decentralization level & 0.994 & 1.107 & 0.294 & 0.155 & 0.247 \\
\hline $\mathrm{H}_{12.1}$ Formalization level & 0.992 & 1.572 & 0.211 & 0.185 & 0.460 \\
\hline \multicolumn{6}{|l|}{ Environmental Context } \\
\hline $\begin{array}{l}\mathrm{H}_{13.1} \text { Market Force } \\
\text { Influence }\end{array}$ & 0.976 & 4.992 & 0.027 & 0.330 & 0.119 \\
\hline $\begin{array}{l}\mathrm{H}_{14.1} \text { Economic downturn } \\
\text { influence }\end{array}$ & 0.976 & 4.816 & 0.029 & -0.324 & -0.244 \\
\hline $\mathrm{H}_{15.1}$ Competitive pressure & 0.996 & 0.807 & 0.370 & 0.133 & 0.659 \\
\hline $\begin{array}{l}\mathrm{H}_{16.1} \text { Regulatory and legal } \\
\text { environment }\end{array}$ & 0.939 & 12.971 & 0.000 & 0.532 & 0.292 \\
\hline $\mathrm{H}_{17.1}$ National e-readiness & 0.988 & 2.445 & 0.10 & 0.231 & 0.346 \\
\hline $\begin{array}{l}\mathrm{H}_{18.1} \text { Technology } \\
\text { consultant's participation }\end{array}$ & 0.880 & 27.389 & 0.000 & 0.773 & 0.965 \\
\hline Wilks' $\lambda=0.815$ & $\mathrm{df}=17$ & \multicolumn{4}{|l|}{$P=0.002$} \\
\hline Canonical $R=0.430$ & $\chi^{2}=39.128$ & \multicolumn{4}{|l|}{$F=27.389$} \\
\hline
\end{tabular}

Note: Percentage of correct classification was $64.3 \%(60.8 \%$ of the non-interactive adopters and $68.2 \%$ of the interactive adopters). Discriminant loadings for variables providing significant contributions to Non-Interactive E-commerce adoption are in boldface. 


\subsection{Interactive E-commerce Adoption}

Interactive E-commerce adoption is operationalized as a dichotomy of whether or not an organisation has attained an interactive E-commerce status. The results of the discriminant analysis together with the descriptive statistics are presented in Table 7. The MDFA produces a statistically significant function (Wilks' Lambda $(\lambda)=0.809\left(\chi^{2}=27.186 ; \mathrm{df}=19 ; \mathrm{F}=1.093\right.$; $\mathrm{p}<0.100$ ) indicating that the model is satisfactorily significant in discriminating adopters and non-adopters of E-commerce. Hence the null hypothesis that in the population the mean averages of all discriminant functions in all groups are equal must be rejected. The function correctly classifies $88.8 \%$ of the organisations in the sample $(98.5 \%$ of interactive Ecommerce adoption and $42.9 \%$ of the transactive E-commerce adoption).

On the basis of the analysis, IT readiness, management team support, regulatory and legal environment and technology consultants' participation are identified as significant and positive contributors to interactive E-commerce adoption. Hence, the results fully support four hypotheses: $\mathrm{H}_{6.2}, \mathrm{H}_{7.2}, \mathrm{H}_{16.2}, \mathrm{H}_{18.2}$ meaning interactive E-commerce adoption is significantly influenced by the participation of technology consultant, information technology readiness, management team support and regulatory and legal environment among the technological, organisational and environmental determinants. Conversely, the remaining factors are found to be poor predictors of the interactive adoption of E-commerce adoption and did not show loading above the cut-off point. 
Table 7. Discriminant Analysis for Interactive E-commerce Adoption

\begin{tabular}{|c|c|c|c|c|c|}
\hline Variables & $\begin{array}{l}\text { Wilks' } \\
\text { Lambda }\end{array}$ & $\begin{array}{l}\text { Univariate F } \\
\text { ratio (Sig.) }\end{array}$ & P (Sig.) & $\begin{array}{l}\text { Discriminant } \\
\text { loadings }\end{array}$ & $\begin{array}{c}\text { Discriminant } \\
\text { Coefficient }\end{array}$ \\
\hline \multicolumn{6}{|c|}{ E-commerce Technology Characteristics } \\
\hline $\mathrm{H}_{1.2}$ Relative advantage & 0.998 & 0.297 & 0.587 & 0.096 & 0.165 \\
\hline $\mathrm{H}_{2.2}$ Compatibility & 0.993 & 0.910 & 0.342 & 0.167 & 0.180 \\
\hline $\mathrm{H}_{3.2}$ Adoption cost & 0.999 & 0.138 & 0.710 & -0.065 & -0.137 \\
\hline $\mathrm{H}_{4.2}$ Security Concern & 0.984 & 2.216 & 0.139 & -0.261 & -0.297 \\
\hline $\mathrm{H}_{5.2}$ Language concern & 0.999 & 0.189 & 0.664 & -0.076 & -0.118 \\
\hline \multicolumn{6}{|l|}{ Organisational Context } \\
\hline $\mathrm{H}_{6.2} \mathrm{IT}$ readiness & 0.969 & 4.424 & 0.037 & 0.369 & 0.427 \\
\hline $\begin{array}{l}\mathrm{H}_{7.2} \text { Management team } \\
\text { support }\end{array}$ & 0.975 & 3.491 & 0.064 & 0.328 & 0.142 \\
\hline $\mathrm{H}_{8.2}$ Learning orientation & 0.989 & 1.598 & 0.208 & 0.222 & 0.007 \\
\hline $\begin{array}{l}\mathrm{H}_{9.2} \text { Receptivity toward } \\
\text { change }\end{array}$ & 0.993 & 1.007 & 0.317 & 0.176 & 0.094 \\
\hline $\mathrm{H}_{10.2}$ Strategic orientation & 0.993 & 0.971 & 0.326 & 0.173 & 0.030 \\
\hline $\mathrm{H}_{11.2}$ Decentralization level & 0.985 & 2.102 & 0.149 & 0.254 & 0.694 \\
\hline $\mathrm{H}_{12.2}$ Formalization level & 1.000 & 0.030 & 0.863 & 0.030 & 0.198 \\
\hline \multicolumn{6}{|l|}{ Environmental Context } \\
\hline $\mathrm{H}_{13.2}$ Market force Influence & 1.000 & 0.040 & 0.842 & 0.029 & 0.275 \\
\hline $\mathrm{H}_{14.2}$ Economic downturn & 0.987 & 1.812 & 0.180 & -0.236 & -0.265 \\
\hline $\mathrm{H}_{15.2}$ Competitive pressure & 0.999 & 0.130 & 0.719 & 0.063 & 0.169 \\
\hline $\begin{array}{l}\mathrm{H}_{16.2} \text { Regulatory and legal } \\
\text { environment }\end{array}$ & 0.969 & 4.418 & 0.037 & 0.336 & 0.179 \\
\hline $\mathrm{H}_{17.2}$ National e-readiness & 0.996 & 0.579 & 0.448 & 0.133 & 0.184 \\
\hline $\begin{array}{l}\mathrm{H}_{18.2} \text { Technology } \\
\text { consultants' participation }\end{array}$ & 0.895 & 16.119 & 0.000 & 0.704 & 0.828 \\
\hline Wilks' $\lambda=0.809$ & $\mathrm{df}=19$ & \multirow{2}{*}{\multicolumn{4}{|c|}{$\begin{array}{l}P=0.100 \\
F=1.093\end{array}$}} \\
\hline Canonical $R=0.437$ & $\chi^{2}=27.186$ & & & & \\
\hline
\end{tabular}

Note: Percentage of correct classification was $88.8 \%$ (98.5\% of interactive E-commerce adoption and $42.9 \%$ of the transactive E-commerce adoption). Discriminant loadings for variables providing significant contributions to interactive adoption of E-commerce are in boldface 


\subsection{Stabilisation of E-commerce}

Stabilisation of E-commerce was only evaluated for organisations that had achieved a transactional web presence and integrated web status. Table 8 illustrates the results of the discriminant analysis.

Table 8. Discriminant Analysis for Stabilisation of E-commerce

\begin{tabular}{|c|c|c|c|c|c|}
\hline Variables & $\begin{array}{c}\text { Wilks' } \\
\text { Lambda }\end{array}$ & $\begin{array}{c}\text { Univariate F } \\
\text { ratio (Sig.) }\end{array}$ & P (Sig.) & $\begin{array}{c}\text { Discriminant } \\
\text { loadings }\end{array}$ & $\begin{array}{c}\text { Discriminant } \\
\text { Coefficient }\end{array}$ \\
\hline \multicolumn{6}{|c|}{ E-commerce Technology Characteristics } \\
\hline $\mathrm{H}_{1.3}$ Relative advantage & 0.945 & 7.374 & 0.008 & 0.400 & 0.442 \\
\hline $\mathrm{H}_{2.3}$ Compatibility & 0.882 & 0.367 & 0.545 & 0.093 & 0.014 \\
\hline $\mathrm{H}_{3.3}$ Adoption cost & 0.959 & 8.493 & 0.004 & -0.448 & -0.118 \\
\hline $\mathrm{H}_{4.3}$ Security Concern & 0.959 & 5.356 & 0.022 & -0.148 & -0.189 \\
\hline $\mathrm{H}_{5.3}$ Language concern & 0.953 & 6.194 & 0.604 & -0.080 & -0.066 \\
\hline \multicolumn{6}{|l|}{ Organisational Context } \\
\hline $\mathrm{H}_{6.3}$ IT readiness & 0.945 & 7.283 & 0.042 & 0.397 & 0.262 \\
\hline $\mathrm{H}_{7.3}$ Management team support & 0.998 & 0.261 & 0.006 & 0.426 & 0.401 \\
\hline $\mathrm{H}_{8.3}$ Learning orientation & 0.976 & 3.033 & 0.032 & 0.331 & 0.282 \\
\hline $\mathrm{H}_{9.3}$ Receptivity toward change & 0.991 & 1.200 & 0.072 & 0.278 & 0.130 \\
\hline $\mathrm{H}_{10.3}$ Strategic orientation & 0.987 & 1.622 & 0.006 & 0.426 & 0.245 \\
\hline $\mathrm{H}_{11.3}$ Decentralization level & 0.971 & 3.818 & 0.782 & -0.043 & 0.368 \\
\hline $\mathrm{H}_{12.3}$ Formalization level & 0.996 & 0.558 & 0.028 & 0.341 & 0.080 \\
\hline \multicolumn{6}{|l|}{ Environmental Context } \\
\hline $\mathrm{H}_{13.3}$ Market force influence & 0.973 & 5.559 & 0.019 & 0.350 & 0.275 \\
\hline $\mathrm{H}_{14.3}$ Economic downtown & 0.981 & 2.418 & 0.039 & -0.319 & -0.276 \\
\hline $\mathrm{H}_{15.3}$ Competitive pressure & 0.957 & 5.658 & 0.237 & 0.182 & 0.048 \\
\hline $\begin{array}{l}\mathrm{H}_{16.3} \text { Regulatory and legal } \\
\text { environment }\end{array}$ & 0.964 & 4.725 & 0.000 & 0.320 & 0.388 \\
\hline $\mathrm{H}_{17.3}$ National e-readiness & 0.990 & 1.273 & 0.058 & 0.294 & 0.242 \\
\hline $\begin{array}{l}\mathrm{H}_{18.3} \text { Technology consultant's } \\
\text { participation }\end{array}$ & 0.937 & 13.549 & 0.000 & 0.566 & 0.002 \\
\hline Wilks' $\lambda=0.732$ & $\mathrm{df}=18$ & \multicolumn{4}{|l|}{$P=0.006$} \\
\hline Canonical $R=0.518$ & $\chi^{2}=36.523$ & \multicolumn{4}{|l|}{$F=1.326$} \\
\hline
\end{tabular}

Note: Percentage of correct classification was $64.8 \%(80.3 \%$ of interactive, $42.9 \%$ of transactive, and $50 \%$ of integrated). Discriminant loadings for variables providing significant contributions to stabilisation of Ecommerce are in boldface. 
The analysis produces a model that is satisfactorily significant in discriminating the various levels of E-commerce stabilisation: transactional and integrated (Wilks's $\lambda=0.732 ; \chi^{2}=$ 36.523 ; df $=18 ; F=1.326 ; p<0.000$ ). With respect to the overall classificatory ability of the discriminating function, the results indicate that the function correctly classified $64.8 \%$ of the organisations in the sample $(80.3 \%$ of interactive, $42.9 \%$ of transactive, and $50 \%$ of integrated). Therefore, the model can be accepted as a valid predictor of the stabilisation of ecommerce adoption.

The independent variables (constructs) that were most significant to the discriminant function are: technology consultants' participation, regulatory and legal environment, cost, strategic orientation, management team support, market force influence, relative advantage, formalization level, learning orientation, market force influence, economic downtown influence and IT readiness. The results fully support the following hypotheses: $\mathrm{H}_{1.3}, \mathrm{H}_{3.3}$, $\mathrm{H}_{6.3}, \mathrm{H}_{7.3}, \mathrm{H}_{8.3}, \mathrm{H}_{10.3}, \mathrm{H}_{12.3}, \mathrm{H}_{13.3}, \mathrm{H}_{14.3}, \mathrm{H}_{16.3}$ and $\mathrm{H}_{18.3}$.

\section{Discussion and Implications}

This study proposed and empirically tested a new Stage-Oriented Model (SOM) of Ecommerce adoption for organisations in Saudi Arabia which could be verified for other similar Arab countries. The empirical evidence supported the idea that the considerable variability between 'Non-Interactive' adopters, 'Interactive' adopters and 'Stabilisation' of E-commerce was due to significantly different technological, organisational and environmental determinants.

Figure 3 summarizes the key findings of the current study. We found that four organisational constructs (IT readiness, management team support, learning orientation and strategic orientation) and four environmental constructs (market force influence, regulatory and legal environment, technology consultants' participation and economic downturn influence) affect Non-Interactive E-commerce adoption. Moreover, the findings suggest two organisational constructs (IT readiness, and management team support) and two environmental constructs (regulatory environment and technology consultants' participation) have significant effect on the Interactive E-commerce adoption. Also, as organisations adopt more sophisticated Ecommerce practices, relative advantage and cost are found to affect organisational Ecommerce adoption. The maturity level of E-commerce adoption is affected by organisational constructs (especially IT readiness, management team support, learning 
orientation, strategic orientation and formalisation), together with environmental constructs related to external pressure from customers and trading partners. The following sections will discuss the research finding in more details

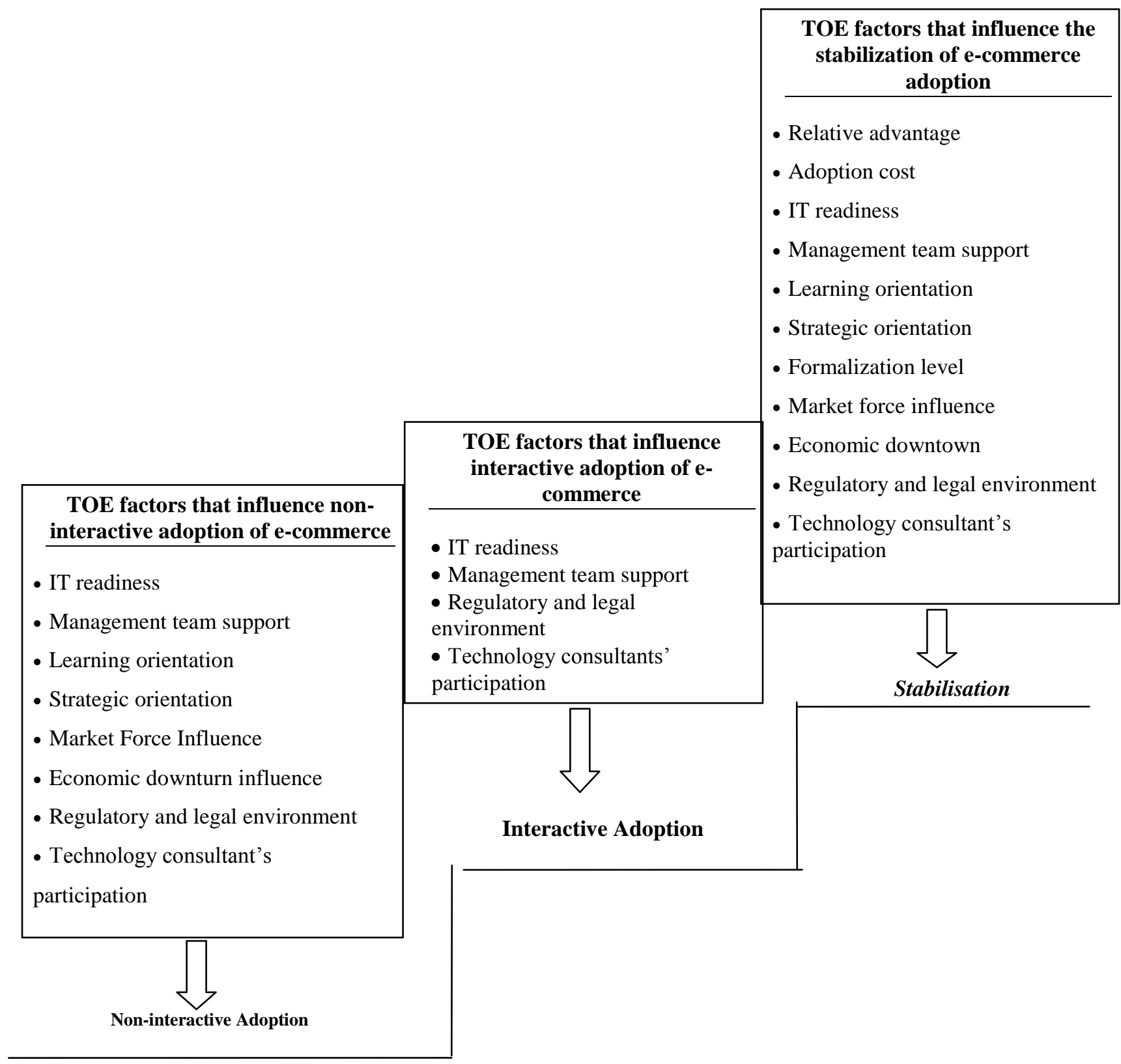

Figure 3: Determinants of E-commerce Adoption in Saudi Arabia

\subsection{E-commerce Technology (T) Characteristics}

As Saudi Arabia organisations adopt and utilise more sophisticated E-commerce practices, cost stands as a major barrier to E-commerce technology. It seems that the extra costs involved (e.g. high telecommunication costs, cost of software development tools for 
integrated computer systems, cost of new computer equipment and high investments necessary) appear to be the primary obstacle for E-commerce. In fact, as these perceived costs rise, it is more likely that overall E-commerce use will be less. However, benefits realised from E-commerce adoption motivate organisations to utilise more E-commerce practices. In fact, in comparison to simple E-commerce applications such as the use of Email and a static website, advanced E-commerce applications such as ECRM ${ }^{4}$ and E-procurement ${ }^{5}$ offer a number of advantages such as increased sales, improved customer services, reduced inventory and procurement costs, improved coordination with suppliers, and increased employee productivity. It is commonly believed that firms that perceive E-commerce as advantageous will be more likely to adopt and routinize the technology. Interestingly compatibility was not found to be significant for any of the three stages of E-commerce technology adoption as surveyed firms viewed E-commerce compatible with their business environments, existing values, practices and IT infrastructure. Previous technological innovation literature and E-commerce research suggests similar observations (Lin and Lin 2008).

Security concern was not found to be significant either for E-commerce adoption, which is consistent with other previous research which found that major issues in developing regions were the insufficient regulatory environment and lack of human and technical resources rather than security issues per se (Molla and Licker 2005a, Mpye et al., 2007).

These findings also suggest that English language was not a barrier to the adoption and stabilisation of E-commerce in Saudi Arabia which is in line with the recent findings suggesting that English language ability was not a factor inhibiting the adoption of Internet and E-commerce use in organisations for countries that used English as a second language (Alam 2009). Indeed, during the last four years many websites have appeared in different languages - including Arabic - further downplaying this factor. Moreover, it is worth noting that since the majority of the informants in this study's sample (80\%) hold Bachelor's and Master's degrees (see Table 5) their command of English is sufficient for them to understand and use the Internet competently.

\footnotetext{
${ }^{4}$ Electronic Customer Relation Management (ECRM) concerns all forms of managing relationships with customers making use of IT.

${ }^{5}$ Electronic procurement (E-procurement) is the electronic purchase and sale of supplies.
} 


\subsection{Organisational (O) Context}

This study found that organisations' technological readiness and employees' IT knowledge are amongst the most important organisational characteristics affecting innovation adoption (Iacovou et al. 1995, Scupola 2003). Moreover, we demonstrate that IT readiness, including tangible resources, intangible skills, and system integration can positively impact the NonInteractive adoption, Interactive adoption and Stabilisation of E-commerce.

This study also found that E-commerce adoption in Saudi Arabian organisations does not depend on the general receptivity toward change held by the organisation's members. However, supportive management and resourceful organisations in terms of human and technological resources are found to encourage innovation adoption. Whereas management of the organisation is a key influencer on the duration of the adoption process of a particular innovation, and favourable managerial attitudes toward change influence and lead to an internal climate conducive toward the innovation. In SA's cultural context, organisational members tend to conform to the expectations of top management, and they are more likely to accept an innovation that they perceive to be backed by the management of their organisation. Moreover, it appears that successful SA E-commerce companies are often the ones where top management champion the E-commerce adoption.

A 'learning orientation' construct was included in the SOM to evaluate a company's ability to develop a spirit of learning and sharing that could offer new products and services through Ecommerce technology. These results suggest that a learning orientation has a significant positive influence on the Non-Interactive and Stabilisation stages of E-commerce technology adoption in SA. This finding is similar to findings from previous innovation adoption studies (Lin and Lin 2008, Rogers 1995) as this study found that when an organisation decides to adopt new E-commerce technology, learning and information sharing among organisational members becomes essential in order to make an adoption decision, gain some understanding of how to use the new technology effectively and to reduce fears and resistance related to the use of the new technology (Rogers 1995). Moreover achieving this allows SA organisations to gain experience and move to the next stage of adoption using familiar related technology. In turn this increases the likelihood of further adoption and an organisations absorptive capacity for E-commerce.

Findings from this study also suggest that strategic orientation has a positive influence on Non-Interactive and Stabilisation stages of E-commerce adoption. Organisations with a well- 
developed strategy will adopt and routinize E-commerce to promote the organisation, its products and services, and to communicate with existing customers more efficiently.

Decentralisation level was not found to be related to E-commerce adoption in SA. It is worth noting that, Middle Eastern management practice can result in large inequalities of power with employees' having a strong dependence on their bosses (Hofstede 1980) which might explain why decentralisation did not turn out to be a contributing factor for E-commerce adoption in SA organisations.

Formalization level was found to be a major construct affecting the Stabilisation and Institutionalisation of E-commerce. This is in line with previous research (Shepard 1967, Zaltman et al. 1973) suggesting organisational formalisation had opposing influences on the innovation process. However this study finds that formalisation is found to be more appropriate and helpful during the implementation stage but not at the initiation and adoption phase. During the initiation and adoption stage, SA organisations needs to be as flexible and open as possible to new sources of information and alternative courses of action. On the other hand it is believed that during the implementation stage a singleness of purpose is required to bring the innovation into practice. Moreover formalised procedures (e.g. rules and processes) are found to help in reducing conflict of opinions and more importantly provide both information and specific techniques that help personnel utilize the innovation (Zaltman et al. 1973).

\subsection{Environmental (E) Context}

Market force influence was found to have strong influence on respondents' Non-Interactive E-commerce adoption and stabilisation. This finding is consistence with previous innovation adoption studies (Iacovou et al. 1995, Molla and Licker 2005a, 2005b). It is believed that Ecommerce use by business partners and customers can create a critical mass of E-commerce adopters and motivate more sophisticated E-commerce applications because of either perceived benefits or fear of market displacement. This shows that firms in developing Arab countries linked to globally distributed customers or universal supply chains are most likely to spearhead E-commerce adoption as their international suppliers and customers may insist on using E-commerce.

Additionally this study shows that when SA organisations face strong economic downturn they tend to reject adoption and investment in E-commerce as economic downturn was 
significantly related to the Non-Interactive adoption and Stabilisation of E-commerce. This finding is consistent with the conventional wisdom that investments in innovation seem to occur more in organisations that are doing well in terms of profits rather than in organisations in financial crisis (Lynch, 2007). However, it is worth noting that the insignificant negative relationship between economic downturn and interactive adoption seems to suggest that the global economic crisis positively impacts and influences SA firms to use E-commerce. Moreover in such conditions SA organisations seem to focus on their websites and social aspects of computing to increase customer responsiveness and to stay closer to their customers. The hypothesised impacts of competitive pressure on E-commerce NonInteractive adoption, Interactive adoption and Stabilisation were not supported. This is in line with the findings of previous studies (Thong, 1999; Wang and Tsai, 2009). In this context it is believed that too much competition is not good for technology assimilation because it drives organisations to chase the latest technologies without firstly fully implementing existing applications.

It seems that, without the necessary physical infrastructure - particularly access to personal computers and effective telecommunications systems at a reasonable cost, organisations are unable to migrate from traditional commerce to E-commerce. However, the results of this study show that the presence of an adequate infrastructure is not a sufficient condition for the development of E-commerce in Saudi Arabia. Moreover, the study finds that the institutional environment, particularly with respect to the 'rule of law', contributes significantly to the development of and investments in E-commerce technologies in developing Arab countries. Therefore, even with access to the necessary equipment, organisations may not become active E-commerce participants unless they have reasonable confidence in the integrity of online transactions and a supporting legal environment. High use and availability of E-commerce in organisations such as banks and chambers of commerce will positively influence this result in the future.

Finally, this study suggests that E-commerce adoption in Saudi Arabia is likely to be facilitated by technology consultants' participation and involvement. In fact, technology consultants and vendors can help organisations develop the capability to solve their problems and achieve a rewarding implementation experience by providing end user training, advocating the innovative use of E-commerce and generally prepare organisations to be more receptive to change. 


\section{Conclusion}

This study has successfully delivered a new Stage Oriented Model (SOM) for E-commerce adoption which includes three different stages (non-interactive, interactive and stabilization) and three types of factors (technological, organisational and environmental) which has not previously been constructed or applied to any dataset before. The testing of the model reveals that it is a valid model that it can be used reliably in this context. The model revealed similar findings on some factors and levels of adoption with other studies using less sophisticated models, further showing its validity. The benefit of this new SOM is that it can measure both stage and factor effects simultaneously whereas other models on which it is partially founded cannot.

Some of the findings from the model's application in SA are surprising as many findings are indeed similar to Western developed nations, which was not expected. However, the notable factors which differ relate to the regulated national environment; the role of women in organisations and the rapidly growing government encouragement for the up-take and financial support of E-commerce growth in SA organisations. The nuances of these issues have been discussed above in respect to stages of adoption and factor types; without the new SOM these might not have been revealed in such detail. Thus the findings from this study have important implications for managers involved in introducing E-commerce into SA organisations, the Middle East or indeed elsewhere.

The study finds that regulatory environment is an important factor that influences the tendency of organisations to adopt e-commerce. Indeed, government support is a critical factor in fostering e-commerce and has an important role in overcoming these concerns and challenges. Previous research suggests that countries adopting new technology must have appropriate government policies and regulations to enhance transactional integrity in online markets, thus encouraging private investment in the new medium (Zhu and Kraemer, 2005; Dewan and Kraemer, 2000; Oxley and Yeung, 2001). Such policies include issues such as intellectual property, consumer protection laws, dispute resolution law and compliance.

For government bodies or others whose task is to support business and promote e-commerce adoption in firms, one implication would be to assist organisations in identifying and incorporating e-commerce technology in the business process which would improve the competitiveness of organisations in the new digital economy. This would also imply finding appropriate ways to identify and transmit the required knowledge to the decision makers of 
these firms. In fact, e-commerce forms part of a broader process of social change, characterised by the globalisation of markets and the shift towards an economy based on knowledge and information. Indeed, e-commerce and its applications such as "smart cards" and automated payment systems are transforming business and also affect the behaviour of individuals, communities, governments and social organisations. These changes will improve the competitiveness of global firms and will give consumers greater convenience and flexibility.

Overall, the study supports the work of Attewell (1992) and Brancheau and Wetherbe (1990), who conclude that people will not simply use new technology because it is there or because they develop a positive attitude towards it. So without using effective intervention strategies and offering suitable learning opportunities, it is difficult to ascertain whether and to what extent organisational members will use the innovation. Moreover, organisational members will increasingly need more time to learn new technological skills in order to remain in business.

Findings from the study suggest that IT readiness influences e-commerce penetration and pervasion in a firm. In fact, access to the physical network and high bandwidth capabilities will clearly affect the take-up and implementation of electronic commerce activities. Organisations that want to engage in e-commerce must have a higher level of internet access in terms of bandwidth and reliability. However, access implies the cost of a subscription to an Internet service provider (ISP) and the costs of equipment and networking. Therefore, connectivity issues will significantly affect organisations involvement in electronic commerce and is believed to be crucial to its development especially for small and mediumsized enterprises (SMEs) and businesses operating in rural and remote areas.

This study also points to important practical implications for technology consultants and software vendors. The study shows that the take-up of new IS innovations is sometimes delayed because decision makers are unaware of the potential benefits of adopting these in the short term as well as in the long term. Generally, lack of awareness of the potential benefits of e-commerce technology can hinder its growth. Therefore, it is essential for technology consultants and vendors to educate firms about the potential benefits of ecommerce by developing a training strategy that actively communicates the benefits of ecommerce through promotional seminars, workshops, presentations and on-site visits stressing that E-commerce is important for productivity and competitiveness. Moreover, consumers can benefit from e-commerce through low prices, better quality and customers and 
the enterprises can reach the most remote markets easily. In addition, e-commerce and ICTs eliminate distance and allow some rural communities to strengthen their social and economic situation. In fact, more time and research will be needed to see to what extent customers and the enterprises are willing to forego such interaction and to see the broader economic and social implications.

All this said there were several limitations in our study. Firstly, these results only reflect SA perspectives; different cultural contexts and environmental settings may generate different results. Secondly, due to our dataset being cross-sectional in nature, we can only show associations, not causality between constructs over-time. Thirdly, we only used a single respondent from each firm where the study utilizes a key decision maker who provides relevant information as the representative of the decision-making unit in an organisation. However, access would have been difficult, and probably would have resulted in a smaller usable sample size from organisations. Therefore, the single respondent approach was adopted. Fourthly, the population of this study was only taken from for-profit manufacturing and service companies. Future tests and refinements of the proposed Stage Oriented Model (SOM) will be conducted in other countries to advance knowledge about the determinants of E-commerce adoption in and beyond the Middle East. 


\section{References}

Aladwani, A. M. (2003). Key Internet characteristics and e-commerce issues in Arab countries. Information Technology and People, 16(1), pp., 9-20.

Alam, S.S. (2009). Adoption of Internet in Malaysian SMEs. Journal of Small Business and Enterprise Development, 16(2), pp.240 - 255.

Alrawi, K W. and Sabry, K. A. (2009) E-commerce evolution: a Gulf region review. International Journal of Business Information Systems, 4(2009), pp.509-526.

Ang, C., Tahar, R.M.; and Murat, R. (2003). An empirical study on electronic commerce diffusion in the Malaysian shipping industry. Electronic Journal of Information Systems in Developing Countries, 14(2003),pp.1-9.

Attewell, P. (1992). Technology diffusion and organisational learning: the case of business computing. Organization Science, 3 (1), pp.1-19.

Boateng, R., Molla, A. and Heeks, R. (2009) E-Commerce in Developing Economies: A Review of Theoretical Frameworks and Approaches. In K. Rouiab, O. Khalil and A.E. Hassanien (eds.), Emerging Markets and E-Commerce in Developing Economies. Hershey: IGI Global, pp.1-56.

Brancheau, J. C. and Wetherbe, J. C. (1990). The Adoption of Spreadsheet Software: Testing Innovation Diffusion Theory in the Context of End-User Computing. Information Systems Research, 1(June), pp.115-143.

Brislin, R.W. (1986) The wording and translation of research instruments. In Lonner, W.J. and Berry, J.W. (Eds.), Field methods in cross-cultural research, Beverly Hills: Sage Publications, pp.137-164

Chiliya, N., Chikandiwa, C. and Afolabi,B. (2011). Factors Affecting Small Micro Medium Enterprises' (SMMEs) Adoption of E-Commerce in the Eastern Cape Province of South Africa. International Journal of Business and Management, 6(10), pp.28-36

Chiu C-M, Wang E.T.G., Fang Y-H, Huang H-Y (2014). Understanding customers' repeat purchase intentions in $\mathrm{B} 2 \mathrm{C}$ e-commerce: the roles of utilitarian, hedonic value and perceived risk. Information Systems Journal, 24(1), pp. 85-114.

Churchill, GA, Jr. (1979) A paradigm for developing better measures of marketing constructs. Journal of Marketing Research, 16(1), pp. 64-73

CIA World Fact book (2012) Country Comparison: Internet hosts. Central Intelligence Agency, Available from: https://www.cia.gov/library/publications/the-worldfactbook/rankorder/2184rank.html, Accessed 17th January 2012.

Cooper, R.B. and Zmud, R.W. (1990). Information Technology Implementation Research: A Technological Diffusion Approach. Management Science, 36(2), pp.123-139.

Cui, L., Zhang, C., Zhang, C., and Huang, L. (2006) Exploring e-government impact on Shanghai firms' informatization process. Electronic Markets, 16(4), pp.312-328.

Damanpour, F. (1991). Organizational Innovation: A Meta-Analysis of Effects of Determinants and Moderators. Academy of Management Journal, 34(2), pp.555-590.

Dewan, S. and Kraemer, K.L. (2000). Information technology and productivity: evidence from country-level data. Management Science, 46 (4), 548-562. 
Dilworth, J. and kochhar, A. K. (2007). Creation of an e-business requirements specification model. Journal of Manufacturing Technology Management, 18(6), pp. 659 - 677.

Doolin, B., Mcleod, L. McQueen, B. and Watton, M. (2003). Internet strategies for establishing retailers: four New Zealand case studies. Journal of Information Technology Cases and Applications (JITCA), 5 (4), pp.3-19.

Francalanci, C. and Morabito, V. (2008). IS integration and business performance: The mediation effect of organizational absorptive capacity in SMEs. Journal of Information Technology, 23(2008), pp.297-312.

Ghobakhloo, M., Arias-Aranda, D. and Benitez-Amado, J. (2011). Adoption of e-commerce applications in SMEs. Industrial Management \& Data Systems, 111(8), pp.1238-1269

Grandon, E. E. and Pearson, J. M. (2004). Electronic Commerce Adoption: An Empirical Study of Small and Medium US Businesses. Information and Management, 42(1), pp.197216.

Gibbs, J., Kraemer, K. and Dedrick, J. (2003). Environment and Policy factors shaping eCommerce diffusion: A cross-country comparison. The Information Society, 19(1), pp.12-35.

Gilaninia, S, Danesh, S, Amiri, M., Mousavian, S, and Eskandarpour, B (2011). Effective Factors on Adoption of E-Commerce in SME Cooperative. Interdisciplinary journal of contemporary research in business, 3(6), pp.13-21

Hafeez, K., Keoy, K.H., Hanneman, R. (2006). E-business capabilities model: Validation and comparison between adopter and non-adopter of e-business companies in UK. Journal of Manufacturing Technology Management, 17(6). pp.806-828

Hair, J. F., Anderson, R. E., Tetham, R. L. and Black W.C. (1995) Multivariate Data Analysis with readings (4th Edition). New Jersey, Prentice Hall.

Hartman, A., Sifonis, J., and Kador, J. (2000). Net Ready: Strategies for Success in the Economy. New York: McGraw-Hill.

Hawk, S. (2004). Comparison of B2C e-commerce in developing countries. Electronic Commerce Research, 14(3), pp. 181-199

Hofstede, G. (1980) Culture's consequences: International differences in work-related values. Beverly Hills: Sage.

Iacovou C.L, Benbasat I. and Dexter A.S. (1995). Electronic data interchange and small organizations: Adoption and Impact of Technology. MIS Quarterly, 19(4), pp. 465-485.

Jarvenpaa,S and Leidner, D. (1998). An information company in Mexico: Extending the resource-based view of the firm to a developing country context. Information Systems Research, 9(4), pp342-361.

KACST. Business Sector Survey (2006) Available from: King Abdul Aziz City of Science and Technology Website: http://www.isu.net.sa/surveys-\&-statistics/busnes.htm, Accessed on 25th January, 2012.

Kaynak, E. Tatoglu, E. and Kula, V. (2005). An analysis of the factors affecting the adoption of electronic commerce by SMEs: Evidence from an emerging market. International Marketing Review, 22(6), pp.623-640 
Kendall, J.D., Tung, L.L., Chau, K.H., Ng, C.H.D., Tan, S.M. (2001). Receptivity of Singapore's SMEs to electronic commerce adoption. Journal of Strategic Information Systems, 10(3), pp.223-42

Kerlinger, F. (1986) Foundations of behavioral research (3rd Edition). New York: Holt, Rinehart and Winston Inc.

Kheng, C.B. and Al-Hawamdeh, S. (2002). The Adoption of Electronic Procurement in Singapore. Electronic Commerce Research, 2(1-2), pp.61-73.

Kohli, A., Jaworski, B. (1990). Market orientation: the construct, research propositions, and managerial application. Journal of Marketing, 54 (April), pp.1-18.

Kshetri, N. (2007). Barriers to E-commerce and competitive business models in developing countries: A case study. Electronic commerce research and applications, 6(4), pp.443-452.

Lertwongsatien, C. and Wongpinunwatana, N. (2003). E-commerce Adoption in Thailand: An Empirical Study of Small and Medium Enterprises (SMEs). Journal of Global Information Technology Management, 6(3), pp.67-83.

Lin, H.-F. and Lee, G.-G. (2005). Impact of organizational learning and knowledge management factors on e-business adoption. Management Decision, 43(2), pp.171-88.

Lin, H. and Lin S. (2008). Determinants of E-business diffusion: A test of the technology diffusion perspective. Technovation, 28(3), pp.135-145.

Lynch, L. M. (2007) The Adoption and Diffusion of Organizational Innovation: Evidence for the U.S. Economy. National Bureau of Economic Research (NBER) Working Paper No.13156. Cambridge, MA.

MacGregor, R.C. and Vrazalic, L. (2006a). E-commerce adoption barriers in small businesses and the differential effects of gender. Journal of Electronic Commerce in Organizations, 4 (2), pp.1-24.

MacGregor, R.and Vrazalic, L. (2006b) .Sector Driven Variations on E-commerce Adoption Barriers in Regional Small Businesses: An Australian Study. In proceedings of the Innovations in Information Technology Conference, IEEE, 19- 21 November, Dubai, UAE.

Marasini, R., Ions, K., Ahmad, M. (2008). Assessment of e-business adoption in SMEs: A study of manufacturing industry in the UK North East region. Journal of Manufacturing Technology Management.19 (5), pp.627-644.

Matopoulos, A., Vlachopoulou, M., Manthou, V. (2009). Understanding the factors affecting e-business adoption and impact on logistics processes. Journal of Manufacturing Technology Management. 20(6), pp.853-865

Molla, A. and Licker, P.S. (2005a). Ecommerce adoption in developing countries: a model and instrument. Information and Management, 42(6), pp.877-899

Molla, A. and Licker, P.S. (2005b). Perceived E-Readiness factors in E-Commerce adoption: an empirical investigation in a developing country. International Journal of Electronic Commerce, 10(1), pp.83-110.

Montealegre, R. (1999). A temporal model of institutional interventions for information technology adoption in less developed countries. Journal of Management Information Systems, 16(1), pp.207-232. 
Mpye D., Osman S. and Van Belle J.P. (2007). Barriers to ICT Adoption for Microbusinesses in South Africa. In proceedings of the 8th Annual Global Information Technology Management Association (GITMA) World Conference, Naples, Italy, 17-19 June 2007

Nunnally, J.C. (1978) Psychometric Theory (2nd Edition). New York: McGraw-Hill.

Oxley, J., and Yeung, B. (2001). E-commerce readiness: Institutional environment and international competitiveness. Journal of International Business, 32(4), 705-724.

Ramsey, E and McCole, P. (2005). E-business in professional SMEs: the case of New Zealand. Journal of Small Business and Enterprise Development, 12 (4), pp.528-544

Rogers, E.M. (1995) Diffusion of Innovations (4th Ed.). New York: The Free Press.

Salavou, H., Baltas, G., and Lioukas, S. (2004).Organisational innovation in SMEs: the importance of strategic orientation and competitive structure. European journal of marketing, 38(9/10), pp.1091 - 1112.

Salman, A. (2004). Elusive challenges of e-change management in developing countries. Business Process Management Journal, 10 (2), 140-157.

Scupola, A. (2003). The Adoption of Internet Commerce by SMEs in the South of Italy: An Environmental, Technological and Organizational Perspective. Journal of Global Information Technology Management, 6 (1), pp.51-71.

Seyal, A.H., Awais, M.M., Shamail, S., and Abbas, A. (2004). Determinants of electronic commerce in Pakistan: Preliminary evidence from small and medium enterprises. Electronic Markets, 14(4), pp.372-387.

Shepard, H. A. (1967). Innovation-Resisting and Innovation-Producing Organizations. The Journal of Business, 40(4), pp.470-477.

Soliman, K.S., and Janz, B.D. (2004). An exploratory study to identify the critical factors affecting the decision to establish Internet-based inter-organizational information systems. Information and Management, 41(6), pp.697-706.

Tan, X., Nah, F., Iacovou, C., and Kim, J. (2003) Factors influencing the adoption of emarketplaces by small organizations: An empirical investigation. In proceedings of the 9th Americas Conference on Information Systems. Florida, USA, 751-757.

Tan, J, Tyler, K. and Manica, A. (2007). Business-to- business adoption of ecommerce in China. Information and Management, 44(3), pp.3321-3351.

Tarafdar, M., and Vaidya , S.D. (2004). Adoption of electronic commerce by organizations in India: Strategic and environmental imperatives. Electronic Journal of Information Systems in Developing Countries, 17 (2004), pp.1-25.

Tarafdar, M., and Vaidya, S. D. (2006). Challenges in the adoption of E-Commerce technologies in India: The role of organizational factors. International Journal of Information Management, 26(6), pp.428-441

Teo, T., Tan, M. and Buk, W. (1998). A contingency model of internet adoption in Singapore. International Journal of Electronic Commerce, 2(2), pp95-118.

Thatcher, S. M.B, Foster, W. and Zhu, L. (2006). B2B e-commerce adoption decisions in Taiwan: The interaction of cultural and other institutional factors. Electronic Commerce Research and Applications, 5(2006), pp.92-104. 
Thong, J. (1999). An integrated model of information systems adoption in small business. Journal of Management Information Systems, 15(4), pp.187-214.

Thong, J. Y. L., Chee-Sing, Y. and Raman, K. S. (1996). Top Management Support, External Expertise and Information Systems Implementation in Small Businesses. Information Systems Research, 7(2), 248-67.

Tornatzky, L.G and Fleischer, M. (1990) The Processes of Technological Innovation. Lexington: Lexington Books.

Terzi, N. (2011). The impact of e-commerce on international trade and employment. Procedia Social and Behavioral Sciences, 24(2011), pp.745-753

Venkatesh, V., Morris, M. G., Davis, B. G. and Davis, F. D. (2003). User acceptance of information technology: Toward a unified view. MIS Quarterly, 27(3), pp.425-478.

Waarts, E., Everdingen, Y. and Hillegersberg, J. (2002). The Dynamics of Factors Effecting the Adoption of Innovations. The Journal of Product Innovation Management, 19(6), pp.412423.

Wang, J.C. and Tsai, K.H. (2009). Factors in Taiwanese Firms' Decisions to Adopt Electronic Commerce: An Empirical Study. The World Economy, 25(8), pp.1145-1168.

Wanyoike, D.M, Mukulu, E. and Waititu, A. G (2012). ICT Attributes as Determinants of Ecommerce Adoption by Formal Small Enterprises in Urban Kenya. International Journal of Business and Social Science. 3(23), pp.65-74

World Bank. World Development Indicators database (2010). Available from: http://data.worldbank.org, Accessed 28th February 2012.

World Economic Forum (2012). Global Information Technology Report 2009-2010: ICT for Sustainability. Available from: http://www3.weforum.org/docs/Global_IT_Report_2012.pdf, Accessed June 2012.

Wu, F., Mahajan, V. and Balasubramanian, S. (2003). An Analysis of E-Business Adoption and Its Impact on Business Performance. Journal of the Academy of Marketing Science, 31(4), pp.425-447.

Zaltman, G., Duncan, R. and Holbek, J. (1973) Innovations and Organizations. New York: Wiley.

Zhu, K., Dong, S., Xu, S. X. and Kraemer, K. L. (2006).Innovation diffusion in global contexts: determinants of post-adoption digital transformation of European companies. European Journal of Information Systems, 15(6), pp.601-616

Zhu, K and Kraemer, K. L. (2005). Post-Adoption Variations in Usage and Value of EBusiness by Organizations: Cross-Country Evidence from the Retail Industry. Information Systems Research, 16(1), pp.61-84.

Zhu, K, Kraemer, K. and Xu, S. (2003). Electronic business adoption by European firms: a cross-country assessment of the facilitators and inhibitors. European Journal of Information Systems, 12(2003), pp.251-268. 


\begin{tabular}{|c|c|c|}
\hline Construct & Item & Measures \\
\hline $\begin{array}{l}\text { Relative } \\
\text { Advantage }\end{array}$ & $\begin{array}{l}\text { RAD1 } \\
\text { RAD2 } \\
\text { RAD3 } \\
\text { RAD4 } \\
\text { RAD5 } \\
\text { RAD6 } \\
\text { RAD7 } \\
\text { RAD8 } \\
\text { RAD9 }\end{array}$ & $\begin{array}{l}\text { E-commerce use will increase business profitability. } \\
\text { E-commerce is useful to expand the market share for existing products/services. } \\
\text { E-commerce is useful to increase international sales. } \\
\text { E-commerce is useful to improve coordination with suppliers and trading partners. } \\
\text { E-commerce is useful to provide a better relationship with our suppliers and trading partners. } \\
\text { E-commerce is useful to improve internal communications and processes. } \\
\text { E-commerce is useful to communicate better with customers. } \\
\text { E-commerce is useful to increase customer satisfaction. } \\
\text { E-commerce is useful to improve customer service. }\end{array}$ \\
\hline Compatibility & $\begin{array}{l}\text { COM1 } \\
\text { COM2 } \\
\text { COM3 }\end{array}$ & $\begin{array}{l}\text { The implementation of E-commerce is/will be incompatible with the firm's IT infrastructure } \\
\text { (R). } \\
\text { The implementation of E-commerce is/will be incompatible with existing hardware (R). } \\
\text { Web applications used in E-commerce are/will be incompatible with existing software and } \\
\text { applications (R). }\end{array}$ \\
\hline $\begin{array}{l}\text { Security } \\
\text { Concern }\end{array}$ & $\begin{array}{l}\text { SEC1 } \\
\text { SEC2 } \\
* \text { SEC3 } \\
* \text { SEC4 }\end{array}$ & $\begin{array}{l}\text { E-commerce is associated with insufficient security safeguards and authentication issues (R). } \\
\text { Internet protocols are inadequate to support secure electronic ordering and payments }(\mathrm{R}) \text {. } \\
\text { Our firm is concerned about cybercrime such as hacking. } \\
\text { E-commerce environment is secure enough. }\end{array}$ \\
\hline Cost & $\begin{array}{l}\text { COS1 } \\
\text { COS2 } \\
\text { COS3 } \\
* \cos 4\end{array}$ & $\begin{array}{l}\text { The costs of E-commerce applications and systems are acceptable. } \\
\text { The cost of access to the Internet is acceptable. } \\
\text { The hosting charge for websites with sufficient bandwidth is acceptable. } \\
\text { E-commerce requires a substantial investment in training for employees to maintain a } \\
\text { multi-skilled workforce. }\end{array}$ \\
\hline \multirow{3}{*}{$\begin{array}{l}\text { Language } \\
\text { Barrier }\end{array}$} & LAB 1 & $\begin{array}{l}\text { More Arabic language websites would encourage our workforce to use more E-commerce } \\
\text { technologies. }\end{array}$ \\
\hline & *LAB2 & We face difficulties in accessing English content websites. \\
\hline & LAB3 & Greater English language proficiencies among our staff would be advantageous. \\
\hline \multirow{7}{*}{ IT readiness } & ITR1 & $\begin{array}{l}\text { Our organisation is highly computerized with internal and external network connections that } \\
\text { connect the firm with its branches (i.e. Local Area Network (LAN) and Wide Area Network } \\
\text { (WAN). }\end{array}$ \\
\hline & ITR2 & We have connectivity to the Internet. \\
\hline & ITR3 & $\begin{array}{l}\text { Our firm has individual(s) with 'expert' knowledge of information technology (IT) and e- } \\
\text { commerce technologies. }\end{array}$ \\
\hline & ITR4 & We have sufficient financial resources to implement E-commerce. \\
\hline & ITR5 & $\begin{array}{l}\text { Our firm has individual(s) who could plan and carry out various parts of the evaluation } \\
\text { procedure of E-commerce implementation. }\end{array}$ \\
\hline & ITR6 & Most of our employees have unrestricted access to computers. \\
\hline & ITR7 & Most of our employees are computer literate. \\
\hline \multirow{5}{*}{$\begin{array}{l}\text { Management } \\
\text { team support }\end{array}$} & MTS1 & $\begin{array}{l}\text { Top managers are willing to try to provide the necessary resources for implementing E- } \\
\text { commerce practices. }\end{array}$ \\
\hline & MTS2 & $\begin{array}{l}\text { Top managers often advise employees to keep track of the latest developments in Internet } \\
\text { technologies and Internet-related business practices. }\end{array}$ \\
\hline & MTS3 & $\begin{array}{l}\text { Our top management is likely to consider the implementation of E-commerce applications as } \\
\text { strategically important. }\end{array}$ \\
\hline & MTS4 & $\begin{array}{l}\text { Top managers in our firm keep telling people that they must bring more of their business } \\
\text { practices online in order to meet customers' future needs. }\end{array}$ \\
\hline & MTS5 & $\begin{array}{l}\text { According to top managers in our firm, incorporating E-commerce practices is a very } \\
\text { important way to gain competitive advantage. }\end{array}$ \\
\hline
\end{tabular}

$\mathrm{R}$ : reverse-coded item

*Highlighted items have not been considered for further analysis 


\begin{tabular}{|c|c|c|}
\hline \multirow{5}{*}{$\begin{array}{l}\text { Learning } \\
\text { orientation }\end{array}$} & LRO1 & Our firm is quick to learn about new technologies. \\
\hline & LRO2 & Supervisors are actively engaged in the learning process and development of their employees. \\
\hline & LRO3 & People in our organisation exchange and share information freely and frequently. \\
\hline & LRO4 & Learning and continuous improvement of the personnel is considered to be a major priority. \\
\hline & LRO5 & $\begin{array}{l}\text { Success or failure is always discussed as part of the learning process and as an opportunity for } \\
\text { learning and improvement. }\end{array}$ \\
\hline \multirow{6}{*}{$\begin{array}{l}\text { Receptivity } \\
\text { toward change }\end{array}$} & RTC1 & We respond well to competitors and other changes in the business environment. \\
\hline & RTC2 & In our organisation, people can easily accept a change in their organisational roles. \\
\hline & RTC3 & $\begin{array}{l}\text { In my organisation, people can easily accept a change in the software applications that they } \\
\text { use. }\end{array}$ \\
\hline & RTC4 & $\begin{array}{l}\text { In our organisation, people are proactive in requesting changes in the software applications } \\
\text { that they use in order to exploit new technologies. }\end{array}$ \\
\hline & RTC5 & Our organisation is capable of dealing with the rapid technological changes. \\
\hline & *RTC6 & Attempts to create change usually meet with resistance. \\
\hline \multirow{3}{*}{$\begin{array}{l}\text { Decentralization } \\
\text { level }\end{array}$} & DEL1 & Only major strategic decisions need to be approved by top management. \\
\hline & DEL2 & Small matters can be dealt with by operational level staff. \\
\hline & DEL3 & Employees who want to make their own decision would be encouraged here. \\
\hline \multirow{3}{*}{$\begin{array}{l}\text { Formalisation } \\
\text { level }\end{array}$} & FOR1 & Whatever situation arises, we have procedures to follow in dealing with the situation. \\
\hline & FOR2 & Every employee has a specific job to do. \\
\hline & FOR3 & When rules and procedures exist here, they are usually well defined in written form. \\
\hline \multirow{9}{*}{$\begin{array}{l}\text { Strategic } \\
\text { orientation }\end{array}$} & STO1 & Our business objectives are driven by customer satisfaction. \\
\hline & STO2 & We measure customer satisfaction systematically and frequently. \\
\hline & STO3 & We give close attention to after-sales service. \\
\hline & STO4 & We keep promises made to customers. \\
\hline & STO5 & Top management regularly discusses competitors' strengths and strategies. \\
\hline & STO6 & We respond rapidly to competitive actions. \\
\hline & STO7 & The policy of the firm has been to always consider the most up-to-date available technologies. \\
\hline & STO8 & $\begin{array}{l}\text { We have a long tradition and reputation in our industry of attempting to be first to try out new } \\
\text { systems, applications, methods and equipment. }\end{array}$ \\
\hline & STO9 & We devote extra resources (i.e. time, money) to technological forecasting. \\
\hline \multirow[t]{7}{*}{$\begin{array}{l}\text { Market Force } \\
\text { Influence }\end{array}$} & MRF1 & $\begin{array}{l}\text { A majority of our customers recommended that we establish strong E-commerce relationships } \\
\text { with them. }\end{array}$ \\
\hline & MRF2 & A majority of our customers requested that we implement E-commerce. \\
\hline & *MRF3 & $\begin{array}{l}\text { Our relationship with our major customers would have suffered if we had not } \\
\text { implemented E-commerce practices }(R) \text {. }\end{array}$ \\
\hline & MRF4 & $\begin{array}{l}\text { A large number of our suppliers and business partners have already adopted E-commerce } \\
\text { practices. }\end{array}$ \\
\hline & MRF5 & $\begin{array}{l}\text { The majority of supplier and business partners recommend the implementation of E- } \\
\text { commerce. }\end{array}$ \\
\hline & MRF6 & $\begin{array}{l}\text { Our business partners and suppliers usually set the mode of communication (e.g., fax, Email, } \\
\text { etc.) }\end{array}$ \\
\hline & *MRF7 & $\begin{array}{l}\text { Supplier and business partners are generally very knowledgeable regarding technical } \\
\text { matters. }\end{array}$ \\
\hline \multirow{3}{*}{$\begin{array}{l}\text { Economic } \\
\text { downturn } \\
\text { Influence }\end{array}$} & ECO1 & $\begin{array}{l}\text { The global economic downturn did not put significant pressure on the firm to cut ICT and e- } \\
\text { commerce applications' costs or budget (R). }\end{array}$ \\
\hline & $\mathrm{ECO} 2$ & $\begin{array}{l}\text { The global economic downturn did not put significant pressure on the firm to cut the training } \\
\text { budget to learn and adopt innovations like E-commerce }(\mathrm{R}) \text {. }\end{array}$ \\
\hline & ECO3 & The global economic crisis did not affect the purchasing power of our organisation (R). \\
\hline \multirow{5}{*}{$\begin{array}{l}\text { Competitive } \\
\text { pressure }\end{array}$} & CMT1 & Competition in our industry is not very intense (R). \\
\hline & CMT2 & $\begin{array}{l}\text { Our firm does not experience competitive pressure forcing us to implement E-commerce } \\
\text { solutions (R). }\end{array}$ \\
\hline & CMT3 & New technology is slow to emerge in our industry. \\
\hline & CMT4 & Our competitors are relatively weak. \\
\hline & *CMT5 & Firms that readily implement new technologies will be competitive. \\
\hline
\end{tabular}


Appendix A (Cont.)

\begin{tabular}{|c|c|c|}
\hline \multirow{5}{*}{$\begin{array}{l}\text { Regulatory \& } \\
\text { legal } \\
\text { environment }\end{array}$} & REG1 & Information about electronic commerce laws and regulations is sufficient. \\
\hline & REG2 & There is adequate legal protection for Internet buying and selling. \\
\hline & REG3 & Information about E-commerce privacy and data protection law are sufficient. \\
\hline & REG4 & Information about consumer protection and conflict resolution is sufficient. \\
\hline & REG5 & $\begin{array}{l}\text { In general, we receive enough information about E-commerce laws and regulations from the } \\
\text { government and chamber of commerce. }\end{array}$ \\
\hline \multirow{9}{*}{$\begin{array}{l}\text { National E- } \\
\text { readiness }\end{array}$} & NRE1 & The telecommunication infrastructure is reliable and efficient to support E-commerce. \\
\hline & NRE2 & $\begin{array}{l}\text { The technology infrastructure of commercial and financial institutions is capable of } \\
\text { supporting E-commerce transactions. }\end{array}$ \\
\hline & NRE3 & The postal service is reliable in its support of E-commerce and E-commerce practices. \\
\hline & NRE4 & The electronic payment facilities are sufficient. \\
\hline & NRE5 & $\begin{array}{l}\text { High quality E-commerce applications and services are available at increasingly affordable } \\
\text { rates. }\end{array}$ \\
\hline & NRE6 & $\begin{array}{l}\text { Wireless lines and wireless communication services are reliable and available at affordable } \\
\text { rates. }\end{array}$ \\
\hline & NRE7 & The current Internet connection speed is sufficient for E-commerce transactions. \\
\hline & NRE8 & The Internet connection is available $24 / 7$. \\
\hline & NRE9 & $\begin{array}{l}\text { There are sufficient individual(s) with 'expert' knowledge of IT and E-commerce } \\
\text { technologies in the labour market. }\end{array}$ \\
\hline \multirow{7}{*}{$\begin{array}{l}\text { Technology } \\
\text { consultants } \\
\text { orientation }\end{array}$} & TCO1 & Our IT consultant/technology vendor solves our firm's problems quickly. \\
\hline & TCO2 & Our IT consultant/technology vendor provides relevant information to our firm. \\
\hline & TCO3 & Our IT consultant/technology vendor provides on-time information. \\
\hline & TCO4 & We are confident in the support we receive from our IT consultant/technology vendor. \\
\hline & TCO5 & Our IT consultant/technology vendor has high integrity. \\
\hline & TCO6 & Our IT consultant/technology vendor gives us reliable information and advice. \\
\hline & TCO7 & $\begin{array}{l}\text { In general, there is efficient support from our IT consultant/technology vendor to support our } \\
\text { move to the Internet. }\end{array}$ \\
\hline \multicolumn{3}{|c|}{ E-commerce Adoption } \\
\hline \multirow{2}{*}{$\begin{array}{l}\text { Non-Interactive } \\
\text { E-commerce } \\
\text { adoption }\end{array}$} & \multirow[b]{2}{*}{ NIA } & Connected to the Internet with Email but no website. \\
\hline & & $\begin{array}{l}\text { Static web: that is, publishing basic organisation information on the web without any } \\
\text { interactivity. }\end{array}$ \\
\hline $\begin{array}{l}\text { Interactive } \\
\text { E-commerce } \\
\text { adoption }\end{array}$ & IEA & Interactive web presence: that is, accepting queries, Email, and form entry from users. \\
\hline \multirow[b]{2}{*}{ Stabilization } & \multirow[b]{2}{*}{ STN } & $\begin{array}{l}\text { Transactive web: that is, online selling and purchasing of products and services including } \\
\text { customer service. }\end{array}$ \\
\hline & & $\begin{array}{l}\text { Integrated web: that is, a website connecting your computer systems with online systems } \\
\text { allowing most of the business transactions to be conducted electronically, such as to record all } \\
\text { sales transactions, update inventory records and generate all appropriate paperwork (i.e. } \\
\text { invoices and receipts). }\end{array}$ \\
\hline
\end{tabular}

